\title{
VISIONES Y SÍMBOLOS EMBLEMÁTICOS EN LA POESÍA DE CERVANTES
}

\section{Emblemas Y Literatura Del Siglo DE ORO}

«Nulla res est sub sole quae materiam emblemati dare non possit» escribe B. Balbinus ${ }^{1}$ a fines del XVII.

Efectivamente, la presencia de los emblemas, empresas, jeroglíficos, pegmas, etc., es muy abundante en toda la literatura del Siglo de $\mathrm{Oro}^{2}$, sobre todo desde la afición humanista a este género.

1 Cit. por Ch. Bouzy, "Emblemas, empresas y hieroglíficos en el Tesoro de la Lengua de Sebastián de Covarrubias», 38.

2 A efectos prácticos no merece la pena distinguir entre los distintos matices de la terminología mencionada, que algunos tratadistas se esfuerzan en discriminar. La bibliografía sobre el elemento emblemático en la literatura del Siglo de Oro crece cada día. Valga remitir, entre otros, a estudios ya clásicos como el de M. PRAZ, Imágenes del barroco; F. CAMPA, Emblemata Hispanica; G. LEDDA, Contributo allo studio della letteratura emblematica in Spagna; J. A. MARAVALL, "La literatura de emblemas en el contexto de la sociedad barroca»; A. EGIDO, «Emblemática y literatura en el Siglo de Oro"; o a la dedicada a obras y autores concretos como las contribuciones de P. HALKHOREE, «Lope de Vega's El villano en su rincón, as emblematic Play»; H. MARTINS, "La Estrella de Sevilla como emblema»; D. W. MoIR, "Lope de Vega's Fuenteovejuna and the Emblemas morales of Sebastián de Covarrubias Horozco»; D. L. SMITH, "Tirso's Use of Emblems as a Technique of Representation in La mujer que manda en casa»; Cull, "Emblem Motifs in Persiles y Sigismunda". Ver la nota 3 del artículo "Emblematics in Calderón's El médico de su honra» de J. CULL, 126, donde recoge algunas fichas más. Como muestra del interés que recientemente se está prestando a este aspecto veánse los dos volúmenes de actas, Literatura emblemática hispánica, y Actas del I Simposio Internacional de Emblemática, donde se hallarán muchos otros trabajos interesantes. Son también básicos dos conocidos libros: J. GÁlLEGo, Visión y símbolos en la pintura española del Siglo de Oro, y S. SEBASTIÁn, Contrarreforma y Barroco. Más reciente es el libro de F. RoDRÍGUEZ DE LA FLOR, Emblemas. Para Calderón ver la edición del auto Triunfar mu- 
Tal presencia no exige, naturalmente, la materialización de todas las partes constituyentes de un emblema tipo, esto es, el mote, el elemento visual y la glosa. Incluso, como recuerda V. Infantes ${ }^{3}$, abundan los loci emblemáticos, que los escritores áureos desarrollan en su creación literaria, sin hacer referencia necesariamente a una ilustración de tipo gráfico. Se rastrean por tanto infinidad de materiales y elementos de calidad emblemática en toda la literatura aurisecular.

La circulación desde la imagen a la palabra y viceversa es constante, y en palabras de otra eminente estudiosa del fenómeno, G. Ledda, «los códigos se alimentan recíprocamente, los estímulos son continuos, palabras e imágenes están conectadas, se entrelazan e influencian ${ }^{4}$. De lo que se trataría, en última instancia, es de ver cómo el emblema en su conjunto "ha influido como forma de pensamiento o estructura artística en la poesía, la narrativa o el teatro», poniendo por «delante de cualquier consideración de orígenes y fuentes el sistema conceptual operativo de los emblemas» ${ }^{5}$. La abundancia de repertorios, la multiplicidad de las fuentes y la calidad mostrenca, en suma, de estos materiales hace imposible en la mayoría de los casos la determinación genética de un determinado uso poético.

Cervantes, obviamente, no queda al margen de esta corriente de emblematismo, aunque hasta hace poco no haya sido este un campo de estudio muy cultivado ${ }^{6}$. Como señala Bernat Vistarini, en el

riendo, ed. facsímil, de I. Arellano, B. Oteiza y M. C. Pinillos. Adapto algunos pasajes de ese trabajo en estas líneas. Hay algunas páginas muy interesantes en Internet sobre emblemática: remito a la mantenida por Bernat Vistarini y Cull «Compendio de emblemas españoles ilustrados» con dirección http://dmi.uib.es/people/ acoca/emblemas.html\#10; y la de Bernat Vistarini sobre Emblemática española en http://www.uib.es/depart/dfe/Bernat.html, desde donde se puede conectar con el Web site de la Universidad de Glasgow, el de la Memorial University of Newfoundland (CA). Un proyecto fundamental en este sentido mantiene Sagrario López Poza en La Coruña con una excelente documentación sobre emblemática (la dirección es http://rosalia.dc.fi.udc.es/emblematica/).

3 «La presencia de una ausencia. La emblemática sin emblemas».

4 «Los jeroglíficos en los sermones barrocos», 128.

5 A. Egido, prólogo a la edición de Alciato, Emblemas, de S. SEbastián, citas en pp. 11 y 13

6 Sobre la poesía, en concreto, que es el tema que ahora me ocupa, hay un trabajo de E. D. LoKos, "El lenguaje emblemático del Viaje del Parnaso", y sobre todo el de A. BERnAT VistaRINI, "Algunos motivos emblemáticos en la poesía de Cervantes». Bernat menciona, entre otros, los trabajos de CULL, "Heroic Striving», "Death as the Great Equalizer», "Emblem motifs»; ÁLVAREZ, "Emblematic aspects of Cervantes' Narrative Prose»; K. L. SELIG, "Persiles y Sigismunda», "The Battle oh the Sheep», "Don Quijote I/8-9", o UlmanN, "An Emblematic»... Bernat examina algunos pasajes del Viaje del Parnaso y otros poemas de La Galatea (los enigmas sobre todo, que dejaré yo a un lado remitiendo a su trabajo). En su nota $20 \mathrm{da}$ 
único trabajo que conozco (aparte del de Lokos sobre el Viaje del Parnaso) que analiza motivos emblemáticos en la poesía cervantina, habría razones para suponer una fuerte presencia de estos elementos en Cervantes, cuya mentalidad está tan asentada "sobre aspectos cruciales del Humanismo renacentista», aunque halla en contra cierto «relativismo moral» poco afecto al rigor didáctico de los emblemas, y una actitud irónica hacia la proliferación de autoridades $^{7}$, tan característica también del género. En todo caso la abundancia de este componente en la poesía cervantina es muy notable, y merece una aproximación de cierto detalle, que intentaré hacer en lo que sigue refiriéndome a la colección de poesía completa de Cervantes editada por V. Gaos ${ }^{8}$.

Hay que tener en cuenta que numerosas menciones aparecen extremadamente lexicalizadas, sin mucha conexión con dimensiones visuales propiamente emblemáticas: es el caso de ciertas repetidas citas del laurel o la palma como signos de victoria o excelencia. Otros elementos a menudo emblemáticos carecen de sentido simbólico al aplicarse literalmente (diamante en su valor de riqueza, poema 31, 114; abejas o trigo en el 36; etc.) ${ }^{9}$. Y en fin, destaca en Cervantes la poca visualización de motivos pertenecientes a los emblemas, como las figuras del Destino o la Vanagloria en el Viaje del Parnaso, que subraya Bernat, y otros ejemplos parecidos.

Mi intención en este trabajo no es hacer una historia completa de cada uno de los motivos, que aparecen en muchos más repertorios de los que cito, ni rastrear sistemáticamente el funcionamiento de los emblemas en la poesía de Cervantes ${ }^{10}$, sino únicamente

una lista de motivos emblemáticos. Un examen más completo, que no era del caso en la interesante ponencia de Bernat, arroja, como se verá muchísimas más ocurrencias, que tampoco yo podré estudiar en su totalidad.

7 BERNAT, «Algunos motivos», 84.

8 Poesías completas, II. Dejo sin tratar el Viaje del Parnaso: ver Lokos y Bernat. Me referiré a los poemas por el número en la edición de Gaos, seguido de los números de versos.

9 Las abejas, por ejemplo, aparecen en infinidad de emblemas (cfr. HENKELSCHÖNE, cols. 919 y ss.) pero en este poema simplemente reflejan la riqueza del labrador rico que tiene abundantes panales. Los pigmeos del poema 176, 7 «volaron sus pigmeos y Golías" no se conectan en el contexto con ningún motivo emblemático relativo a los pigmeos (hay dos principales: pigmeos luchando con las grullas o con Hércules: HENKEL-SCHÖNE, cols. 823-24, 1653, con emblemas de Nicolás Reusner y Alciato, emblema 58). Para Bernat son motivos emblemáticos, pero hay que tener en cuenta también la función o la inserción de la imagen en la estructura poemática.

10 Para el deseable estudio total de los emblemas en la poesía de Cervantes habría que delimitar con más precisión el uso emblemático o no de ciertos motivos, listarlos exhaustivamente, cotejarlos con los repertorios en su orden cronológico, y analizarlos en los contextos en que se localizan, etc. El presente trabajo es sólo una aproximación parcial que continúa la de Bernat y que se centra en las ocu- 
poner de relieve la importancia de este tipo de referencias, aportando, a modo de ilustración parcial, algunos comentarios.

En ciertos casos un emblema se aplica en la colección correspondiente a otro propósito distinto del que anima el uso cervantino, pero la polivalencia de muchos emblemas ${ }^{11}$ es conocida, y no anula el valor ilustrativo de los ejemplos seleccionados.

Bernat Vistarini sugiere algunos libros de emblemas que Cervantes pudo ver (Alciato, quizá en la edición del Brocense de 1573; la muy difundida Declaración magistral de los Emblemas de Alciato de Diego López, Nájera, 1615; los Triunfos morales de Francisco de Guzmán, 1557; las Empresas morales de Juan de Borja, 1581; los Emblemas morales de Juan de Horozco, 1589; las Emblemas moralizadas de Hernando de Soto, 1599, o las Empresas espirituales de Francisco de Villava, 1613, principalmente). Dada la extensión de los motivos emblemáticos, a menudo inspirados en fuentes clásicas muy reiteradas en centones, comentarios, polianteas, etc., es superfluo buscar las fuentes concretas de Cervantes y resulta legítima también la ilustración con un repertorio posterior a su obra (como por ejemplo las Empresas políticas de Saavedra Fajardo).

Del análisis se desprende, no obstante, que con mucha probabilidad los repertorios mejor conocidos de Cervantes son los de Alciato, Borja, y Villava, que incluyen una buena parte de las referencias que se localizan en sus versos.

\section{Emblemas en la poesía de Cervantes}

El conjunto de referencias localizables en la poesía cervantina muestra un elevado grado de estructuración: Cervantes no usa emblemas de manera arbitraria ni ocasional, sino que los articula

\footnotetext{
rrencias que creo más significativas del corpus poético cervantino. Complementa también mi artículo "Motivos emblemáticos en el teatro de Cervantes», Boletín de la Real Academia Española, 77, 1997, 419-43. Algunas referencias se reiteran en ambos trabajos. Una versión inicial del presente fue expuesta como conferencia plenaria en un simposio cervantino de la Universidad de Kioto en octubre de 1997, en cuyas actas (en prensa) aparecerá en esa forma reducida y provisional, que completo ahora.

11 Por ejemplo, la paloma es símbolo de los ingratos y también de candidez, pureza y bondad, o de la lujuria (ver Horapolo, Hieroglyphica, 157-159); la salamandra es para Villava ejemplo de los que persisten en el mal a pesar del amor divino y para Camerarius símbolo de los íntegros, etc. Basta revisar el amplio catálogo de Valeriano para ver la cantidad de atribuciones que puede sustentar un mismo elemento. Aunque en una colección determinada pueda aparecer un motivo con sentido diferente del que aquí comento, me considero libre de tomarlo como ilustración gráfica de otro sentido que no resulte arbitrario, sino que venga recogido en otros catálogos.
} 
en varios núcleos especialmente favorecidos, de acuerdo a ciertos géneros habituales en la poesía aurisecular, que podrían esquematizarse como sigue:

a) Hay, primero, una serie de motivos asistemáticos que pueden surgir en contextos diversos, con sentidos matizados por estos contextos.

b) Definición del amor, y configuración del amante y la amada sobre la base de motivos emblemáticos. Es quizá el área fundamental en la poesía de Cervantes, y obedece sin duda a la gran representación de poesía en $L a$ Galatea, y a la importancia del tema amoroso en la literatura pastoril.

c) Motivos en torno a la alegoría de la Fama y al tema de la gloria poética. Es fundamental en este terreno el Canto de Caliope de $\mathrm{La}$ Galatea, pero motivos como la palma o el laurel asoman por todos los versos cervantinos.

d) Motivos característicos de temas morales y sacros, ámbitos privilegiados para el tono emblemático con sus capacidades de didactismo y elevación simbólica. Destacan aquí los poemas dedicados al tema del menosprecio de corte (núm. 38), los dos sobre la profesión religiosa de Fray Pedro Padilla $(163,164)$, y la Canción a la Virgen de Guadalupe del Persiles (150).

e) Poemas de tipo cortesano y épico, igualmente propicios al material emblemático: han de subrayarse los poemas a la Armada contra Inglaterra $(171,172)$, y el romance a la misa de parida de la reina Margarita en La Gitanilla (131).

Veamos en un somero repaso las principales ocurrencias ordenadas sobre este trazado general.

\subsection{Motivos generales de presencia asistemática}

Aparece una notable serie de motivos no ligados a un género preciso, o bien de ocurrencia ocasional en un contexto que no se reitera. A esta clase pertenecen algunos de suma importancia en los repertorios y en el universo ideológico del tiempo y del propio Cervantes.

Así, por ejemplo, el de la Fortuna, descrita en el Canto de Calíope $(59,809-12)$ con sus atributos de rueda voltaria, ligereza y movilidad, imposible de fijar, a la que se contrapone en el poema 159, 36-41 la virtud de Mateo Vázquez, quien no debe su encumbramiento a la inconstancia y falsedad de la Fortuna y su presurosa rueda, sino a su trato y vida honrosa: 
no la inconstante rueda presurosa de la falsa fortuna, suerte o hado, signo, ventura, estrella ni otra cosa dicen ques causa que en el buen estado que agora poseéis os haya puesto...

No hay que buscar, evidentemente, una fuente concreta a esta imagen tópica de la Fortuna, «gran leit motiv de la mentalidad renacentista» ${ }^{12}$ repetida en numerosos libros de emblemas, casi

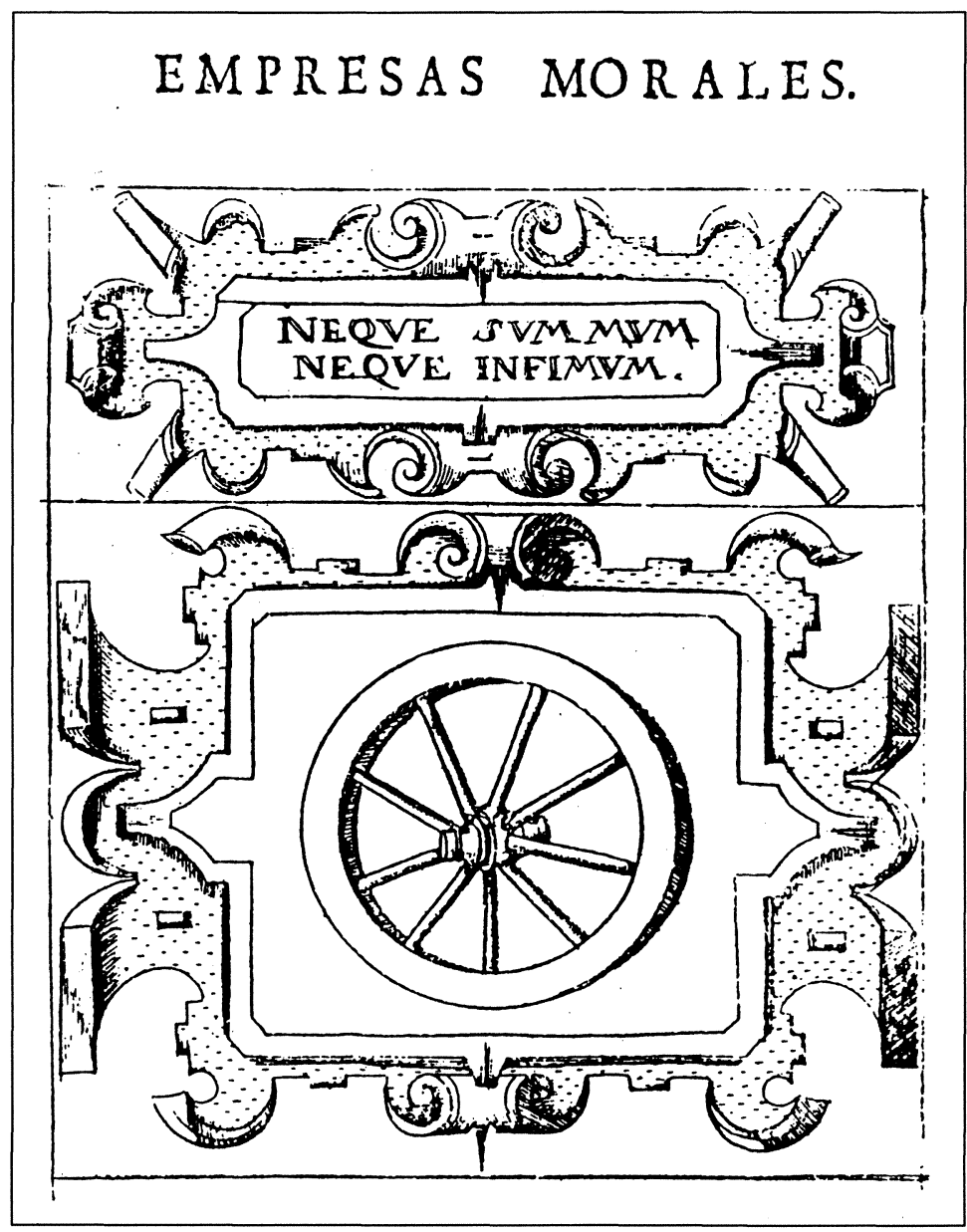

Rueda de la Fortuna (Borja)

12 S. Sebastí́n, Emblemas de Alciato, p. 156. Jean Cousin realizó en París, 1568, una colección de doscientos dibujos sobre el tema en el Liber Fortunae. 
siempre con la acostumbrada iconografía. En Alciato (emblema 98) se opone la firmeza de Hermes (que descansa sobre un cubo de piedra) a la inestabilidad de la Fortuna, cuyos pies descansan sobre una bola rodante. Lleva tapados los ojos, y una vela sobre la que sopla el viento variable. Juan de Borja (pp. 152-53) reproduce en su grabado el atributo esencial de la rueda, con el mote «Neque summun, neque infimum», para expresar la variedad de las cosas del mundo, comparable a una rueda que continuamente se menea, confundiendo lo alto y lo bajo. Villava (II parte, fol. 70), que ha elegido otra ilustración (una tortuga elevada para ser dejada caer por un águila) comenta, sin embargo, con detalle, la alegoría más habitual de la Fortuna a quien «diéronle por empresa una rueda para significar su inconstancia y variedad, y que muchas veces al que empina es para derribarlo, como se ve en la rueda de una noria, que el arcaduz que sube lleno es para que baje vacío». Horozco, Ripa, Covarrubias Horozco, Corrozet, Vaenius, Hadrianus Junius, entre otros ilustran este motivo ${ }^{13}$. El grabado de Andrés Mendo (documento 51) es de los más completos: mujer alada, con la rueda en la mano, la vela para recoger el viento con el mote «Fortuna vitrea est» (esto es, frágil como el cristal), y los pies alados en sendas bolas rodantes: "tiene alas y desaparece veloz; pisa sobre globos de vidrio que ruedan y se quiebran fácilmente».

Del mismo ámbito es la calva Ocasión, que don Belianís, según dice a don Quijote, trae cogida por el copete (83, 9-11), lo que no ha podido hacer el ejército enviado contra Inglaterra, cuyo fracaso se justifica en el poema 172 porque

$$
\begin{aligned}
& \text { ni puede en ningún tiempo los cabellos } \\
& \text { tener alguno con la mano asidos } \\
& \text { de la calva Ocasión en suerte buena (vv. 21-23) }
\end{aligned}
$$

El emblema 121 de Alciato «In Occasionem» ilustra este concepto con iconografía muy cercana a la de la Fortuna, que insiste en la inestabilidad y rapidez: la Ocasión navega en un mar movedizo sobre una rueda, y lleva alas en los pies, una navaja en la mano y el copete al viento sobre la frente, por el que debe cogerla el avisado en el momento en que se presenta, pues la parte posterior de la cabeza es una calva inasible. Diego López ${ }^{14}$ lo explica: «viendo la buena ocasión le habemos de echar la mano y no dejarla pasar, y

13 Ver Horozco, Libro I, 38r: «lo más ordinario se pintaba con la rueda por la poca firmeza que tiene»; RIPA, I, 440 y ss. (con variedad de representaciones); para el resto de emblematistas ver HENKEL-SCHÖNE, cols. 1552, 1797 y ss.

${ }_{14}$ Ed. S. Sebastián, p. 161. Más ilustraciones de la Ocasión en HeNKEL-SchöNE, cols. $1810-11$. 


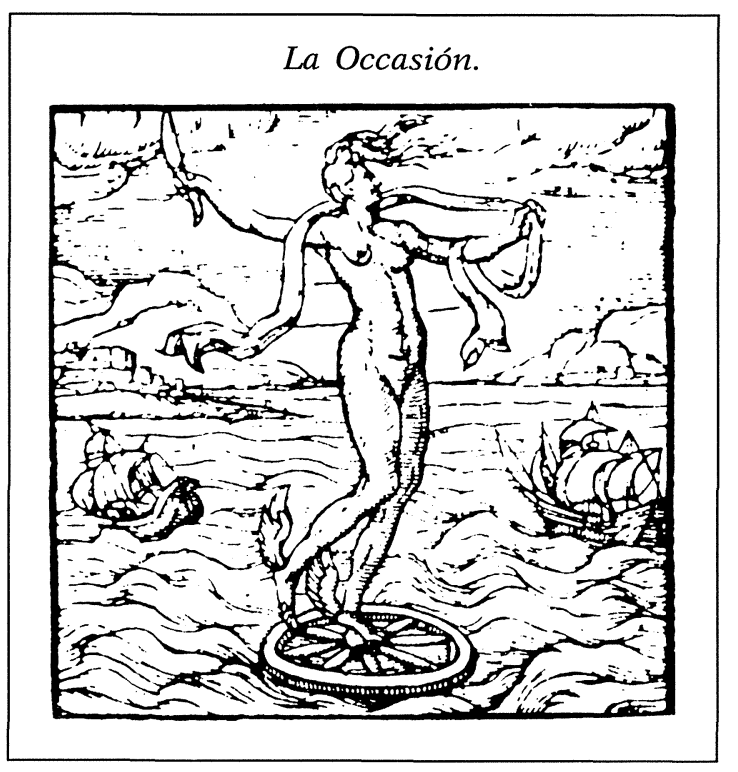

La Ocasión (Alciato).

por esto tiene el cabello en la frente para que nos aprovechemos de la buena ocasión, y tener la postrera parte de la cabeza calva significa que en pasando no hay por dónde la podamos coger».

El Deseo, el Pensamiento o el Tiempo son otros personajes que aparecen en las poesías cervantinas con semejantes rasgos de volatilidad e inconstancia.

El Deseo es alado (Canción de Lisandro, 4, 81), como en Ripa (I, 269-70) para significar la presteza en actuar; el Pensamiento (sobre todo amoroso) se vuelve a todas partes vanamente sin sosegar jamás (poemas $8,1-2 ; 38,1-3$ «El vano imaginar de nuestra mente / de mil contrarios vientos arrojada / aquí y allá con curso presuroso»; 38, 65-66 «Vuelva y revuelva, en alto suba o baje / el vano pensamiento el hondo abismo»: ver Ripa, II, 193-94, que lo representa con alas en la cabeza y vestido de muchos colores).

El Tiempo, muy frecuente en los versos de Cervantes, "pasa y vuela» $(6,3-4)$; «ligero vuela» $(14,28)$; «con alas vuela el Tiempo presurosas» $(23,81)$; es ligero $(29,29)$; vuela presuroso $(60,27)$; vuela ligero sin retorno posible $(117,30-31)$, etc., como corresponde a su representación emblemática de viejo alado «de acuerdo con el dicho Volat irreparabile tempus» (Ripa II, 360-61) que reproducen prácticamente todos los repertorios: Horozco, libro II, emblema 9 (aquí es un reloj con alas sobre una calavera y debajo de una vela); libro III, emblema 29 (viejo alado con guadaña en una mano, antorcha en la otra y cojo), o los que recogen Henkel-Schöne, cols. 1340 y ss., 1813-14.

Más ocasionalmente menciona Cervantes a las Parcas $(34,25$; $59,10)^{15}$ o el funesto ciprés $(58,82)^{16}$, como expresiones de la muerte.

15 Ver Horozco, Libro I, 37r.

16 AlCiato, emblema 198; HenKel-SCHÖNE, 215 y ss. 


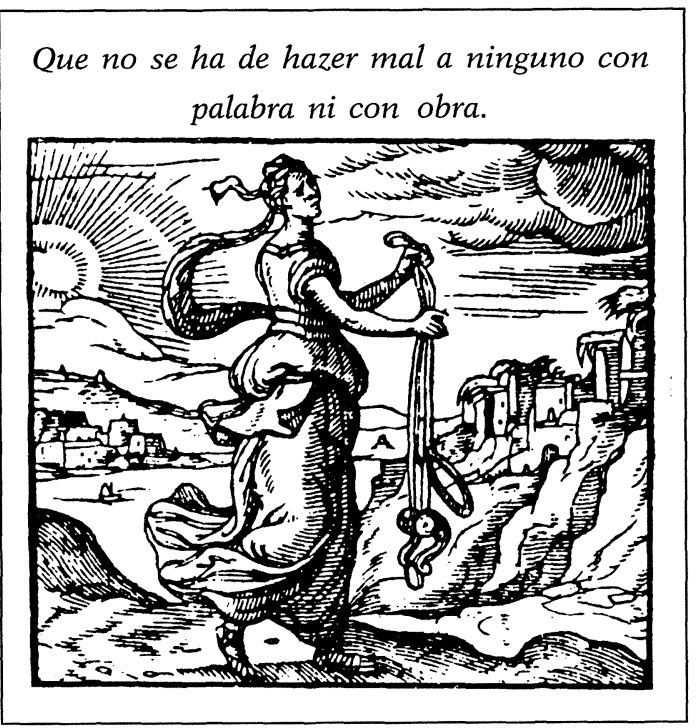

Némesis con el freno (Alciato).

Algo menos tópico aparece un objeto simbólico como el freno, sujetando a la envidia en el Canto de Caliope (59, 779). Ésta es efectivamente la significación emblemática del freno, generalmente acompañado de las riendas, en manos de la diosa Némesis, como en el emblema 27 de Alciato en el que invita a refrenar la lengua de los maldicientes. En el 46 de Alciato aparece otra vez Némesis con las riendas y el freno, atributos que recuerda igualmente Horozco

(Libro I, 37r.) y Gilles Corrozet ${ }^{17}$. Saavedra Fajardo utiliza el freno y las riendas en su empresa 21 como ejemplo de la ley, la razón y la política que deben regir las acciones del príncipe.

El Alcázar como expresión del cielo o patria celeste (poemas 130, $34 ; 156,172)$ tiene fundamento o extensión emblemática numerosa en el Siglo de Oro, sobre todo en el ámbito religioso (es imagen favorita en los autos sacramentales de Calderón) ${ }^{18}$, y se relaciona con la Iglesia, y la "Ciudad de Dios» o Jerusalén triunfante. Núñez de Cepeda ${ }^{19}$ en sus Empresas sacras (empresa XXXVIII) representa una ciudad amurallada, jalonada con torres de vigía, que es la ciudad de Dios, la Iglesia. Otra empresa del mismo en que aparece una ciudad fortificada como refugio contra las asechanzas del mal es la XXIII.

El retrato del príncipe prudente que se esboza en la Glosa de Silerio (poema 24) no olvida mencionar las dos cualidades de justicia y misericordia (vv. 15-16), sin carácter visual en Cervantes, pero obedientes a la misma concepción emblemática que recurre a diferentes visualizaciones en los tratadistas: Horozco (Libro III, emblema 30) glosa la empresa de las granadas, del rey Enrique IV, que con el mote "Agro dulce» da a entender en la mezcla de sabores

\footnotetext{
17 HENKEL-SCHÖNE, col. 1812.

18 Ver Triunfar muriendo, estudio emblemático en la ed. citada, y BLANCo, "La imagen del castillo».

19 Ver R. García Mahiques, Empresas sacras de Núñez de Cepeda.
} 
«la que ha de haber entre la misericordia y el rigor», siguiendo el modelo de Dios, caracterizado por el equilibrio entre la Justicia y la Misericordia. Más frecuente es la representación de la espada con el ramo de olivo que se halla en Emblemata politica de Isselburg (Henkel-Schöne, col. 215). Para la espada de la justicia no hacen falta textos; sobre la oliva, como símbolo de paz y de misericordia comenta largamente C. a Lapide, XII, 815, 1: «Unde ostia oraculi in templo Salomonis facta erant ex olea, quae est symbolum misericordiae»; en XIII, 471, 1: «Ecclesiam et sanctum quemlibet vocari olivam ob fecunditatem bonorum operum, ob praestantem charitatem, misericordiam, lenitatem et splendorem virtutum, horum enim symbolum est oleum»; en IX, 641, 1: «oliva symbolum est primo misericordiae, secundo pacis, tertio victoriae, quarto mansuetudinis; nihil enim lenius et tranquillius oleo». C. Ripa, Iconología, II, describe el emblema de la Justicia Divina: «Sostendrá con la diestra una espada desnuda, sujetando con siniestra una balanza [...] Las balanzas significan que la divina justicia marca la pauta de todas las acciones, mostrándose con la espada las penas que les aguardan a quienes fueron delincuentes» (p. 9); la Misericordia (íd., II, p. 88): «Llevará en la cabeza una corona de olivo [...] [que] es símbolo de la Misericordia que aparece repetidamente en las Sagradas Escrituras, donde se expresa la obligación y el verdadero conocimiento de tan santa virtud». Están ambas en el escudo de la Inquisición.

Andrés Mendo, por su parte (documento 33) pasa revista a otras formulaciones: abejas que producen miel, pero castigan con el aguijón; la granada de Enrique IV ya vista; sol que siendo benéfico quema a veces...

Para terminar este apartado será oportuno comentar el motivo que con mayor frecuencia quizá aparece en las poesías cervantinas, reiterado tanto en la definición del amor, como en los motivos morales de los peligros del mundo y de la corte o en la expresión de la misma cualidad agitada y peligrosa de la vida humana. Me refiero al mar tempestuoso, a la vida como navegación y a las naves contrastadas por las tormentas y los temporales.

El segundo soneto de Damón de La Galatea (47, 1-4) comienza con la imagen del mar tormentoso en el que navega la flaca nave de la vida humana:

Si el áspero furor del mar airado por largo tiempo en su rigor durase, mal se podría hallar quien entregase su flaca nave al piélago alterado. 
El pasaje citado apunta un alcance general que en otros contextos adquiere matices diversos: puede tener sentido religioso como en el poema 163, 25-28 donde el mar significa el mundo que debe salvar el marinero práctico dirigiéndose a Dios, o de lección moral en torno a los riesgos de la vida cortesana, como en la Epístola a Mateo Vázquez $(159,22-24)$ o en la loa al libro de Alonso de Barros, Filosofía cortesana moralizada (168, 9-11):

\author{
se ve entre las ondas anegarse \\ del mar de la privanza, do procura \\ o por fas o por nefas levantarse. \\ El que navega por el golfo insano \\ del mar de pretensiones verá al punto \\ del cortesano laberinto el hilo.
}

Las ocurrencias más frecuentes se refieren al amor, representado como mar alterado que anega al amante, símbolo de las frustraciones y dolores de la pasión. Me ocuparé de este simbolismo en el apartado siguiente.

En los repertorios emblemáticos es uno de los motivos favoritos: Alciato recoge un texto de Horacio sobre la nave del estado, aplicando su emblema 43 a la esperanza cercana ("Spes proxima»), representada como una nave en alta mar, sufriendo los embates de la tempestad. La nave que sufre tormenta puede expresar alegóricamente los trabajos de la Iglesia (nave de la Iglesia), los riesgos de la política (nave del estado), o la condición de la vida humana en general, que ha de ser regida por pilotos como la razón, la prudencia o la filosofía. En Mendo (documento 43) la nave contrastada en alta mar por los vientos es un símbolo de la guerra que fatiga al pueblo: «soplando con furor los vientos contrarios, el mar se altera en borrascas y tempestades deshechas, y la mísera navecilla maltratada de la indignación de ambos elementos, en vaivenes peligrosos fluctúa y hace agua»... En el documento 71 el interés se centra en el piloto sagaz que echa el ancla para evitar que la nave se anegue, y glosa: «Es navegación por el piélago del mundo la vida de los hombres combatidos de continuas olas en que muchos padecen miserable naufragio; es nave la república».

La importancia de este símbolo resulta evidente en la colección de Borja, que dedica media docena de empresas a esta navegación que "comenzamos cuando nacemos y acabamos cuando morimos" (pp. 10-11), y que requiere toda la pericia del buen piloto: «esto mismo debe hacer el hombre prudente y cuerdo cuando se viere ya haber muchos días que navega sin saber cuál será el suceso desta navegación, que es la vida que se vive, para excusar los peligros 


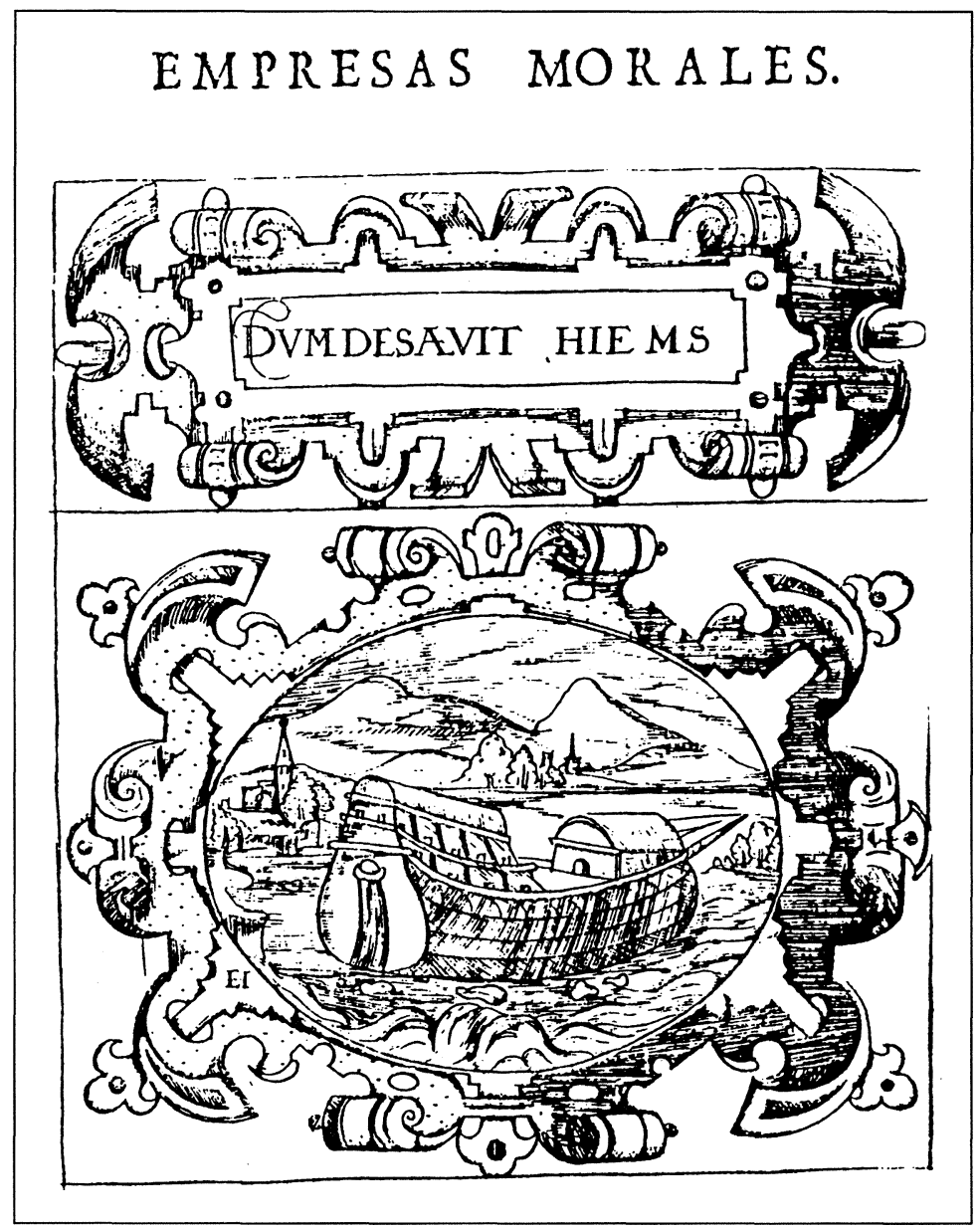

La nave de la vida (Borja).

y tempestades que hay en este mar del mundo y en sus ocupaciones» ${ }^{20}$.

Como he señalado, Cervantes apela a esta imagen sobre todo en los poemas de tema amoroso, que presentan en su conjunto el catálogo más rico y estructurado de motivos emblemáticos en toda la poesía cervantina. Convendrá revisar este territorio con algo más de espacio examinando sucesivamente la representación de la pa-

20 Ver también en pp. 48-49, 110-11, 192-93, 286-87 otras empresas con naves. Añádase Piero VALERIANo, fols. 284 y ss.; HeNKEL-SCHÖNE, cols. 1453 y ss., con numerosas representaciones de todos los matices. 
sión amorosa en sí (focalizada en el personaje alegórico de Cupido), y la de sus dos protagonistas, amada y amante.

\subsection{Emblemas en torno al amor}

\subsubsection{El amor: Cupido y sus atributos}

En La Galatea, que incluye la mayor cantidad de versos en los libros de Cervantes, el tema amoroso es nuclear, y se expresa constantemente en imágenes emblemáticas, a partir de un centro que podemos considerar básico, el de Cupido o dios Amor, que aparece en retratos completos o a través de atributos parciales, como el arco, las saetas, el lazo, las alas o la antorcha de fuego. Los diversos lugares cervantinos siguen ceñidamente los aspectos tópicos; véanse algunos ejemplos:

$$
\begin{aligned}
& \text { Creí que el fuego que en el alma enciende } \\
& \text { el niño alado, el lazo con que aprieta, } \\
& \text { la red sotil con que a los dioses prende, } \\
& \text { la furia y el rigor de su saeta... }(1,17-20) \\
& \text { Afuera el fuego, el lazo, el hielo y flecha } \\
& \text { de amor, que abrasa, aprieta, enfría y hiere, } \\
& \text { que tal llama mi alma no la quiere } \\
& \text { ni queda de tal nudo satisfecha... }(5,1-4) \\
& \text { Sin que me pongan miedo el hielo y fuego } \\
& \text { el arco y flechas del amor tirano, } \\
& \text { en su deshonra he de mover mi lengua, } \\
& \text { que ¿quién ha de temer un niño ciego } \\
& \text { de vario antojo y de juicio insano... }(39,1-5)
\end{aligned}
$$

Las saetas aparecen en sus dos versiones («buenas y malas / saetas», 23, 42-43): las de oro que provocaban el amor y las de plomo que provocaban el odio $(3,14 ; 15,18 ; 26,17-18 ; 56,50)$. Los otros componentes se reiteran: pueden acumularse ejemplos de las alas del amor $(23,41)$, fuego $(1,25)$, etc. Es el modelo descrito por Alciato, emblema 107 "Vis Amoris», que representa a Cupido con arco y flechas y alas, habiendo quebrado el rayo para demostrar que es más fuerte que el fuego. Villava (II, fol. 13 v.) señala que «se finge ciego el deshonesto amor, y con arco y flechas, porque las tira derechamente a los ojos, no solo a los espirituales, siendo uno de sus efectos ceguedad», y Piero Valeriano (fol. 356 v.) glosa el símbolo del lazo como alusión al amor "amorem hieroglyphice significat». Numerosos emblemas de Corrozet, Vaenius, Jacob Cats, Hooft, etc., representan el poder del amor por el fuego, con la alegoría tópica de Cupido (Henkel-Schöne, col. 135). 
Frente al Amor se erige la figura de Anteros, el amor divino o el amor honesto. Cervantes aduce esta oposición en el poema 9, 3744, glosa de Elicio, que pondera el amor platónico capaz de elevar el alma del amante hacia las alturas:

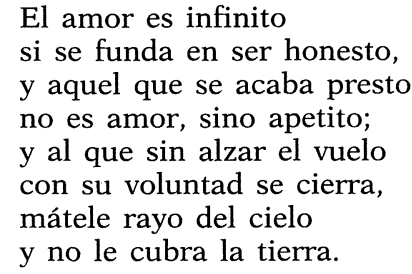

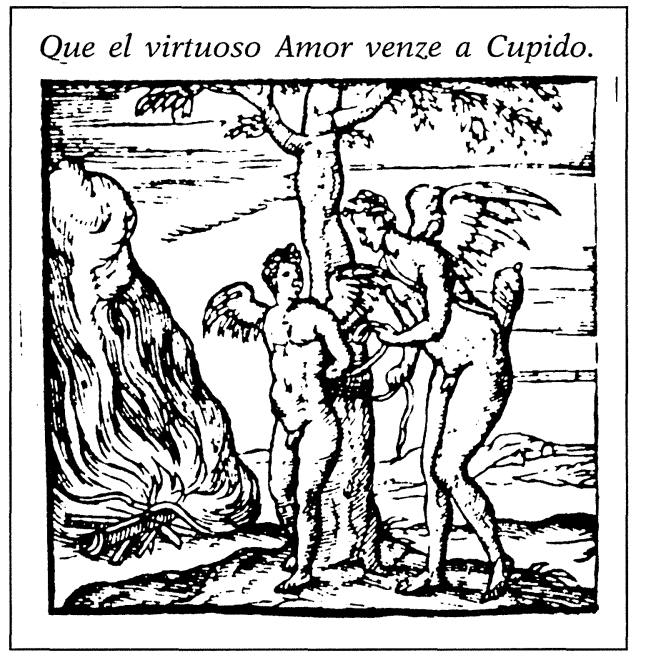

Amor de la Virtud vence a Cupido (Alciato).
La distinción entre amor sensual y espiritual es doctrina muy fatigada en las teorías amorosas ${ }^{21}$ : como escribe León Hebreo "Hay dos clases de amor. Una de ellas la origina el deseo o verdadero apetito sensual, por el que cuando un hombre desea a alguna persona, la ama; es un amor imperfecto porque depende de un principio vicioso y frágil, y viene a ser un hijo engendrado por el deseo [...] La otra clase de amor [...] no proviene del deseo o apetito; por el contrario, como se ama primero perfectamente,

la fuerza del amor hace que se desee la unión espiritual» ${ }^{22}$. En tres emblemas de Alciato $(9,109,110)$ aparece Anteros, «Id est, Amor Virtutis» (emblema 109) que «despierta al hombre a contemplar las

21 Ver PÉrez DE Moya, Filosofía secreta, I, lib. 2, pp. 247-48: «Cupido, que es el amor o carnal deseo, hace llagas en el corazón, porque el que ama ya no está sano en sus pensamientos y deseos". BALTASAR DE VITORIA, Teatro de los dioses, segunda parte, p. 387, adopta el pensamiento agustiniano sobre el amor profano: «Llamaron los antiguos al amor profano Cupido, y es derivado de este nombre "Cupiditas», que quiere decir un amor desordenado y demasiado, o como dice San Agustín "Cupiditas est improba voluntas». Es una voluntad estragada, mala y desordenada, y así Cupido no sólo se toma por el deseo de la hermosura y belleza y por el deseo torpe y deshonesto".

22 Diálogos de amor, 150-151. 
cosas divinas y celestiales, y les da toda virtud y honestidad» (Diego López). En el 110 Anteros vence al otro Cupido, quemando en una hoguera su arco y flechas. En un emblema de Vaenius ambos amores se disputan una palma, iconografía habitual ${ }^{23}$.

El poderoso amor, sin embargo, es vencido por el Interés, según se manifiesta en la danza de las bodas de Camacho (119), concebida sobre inequívocos modelos emblemáticos, con los cortejos de Cupido y de Interés en dos hileras de ninfas: "de la una hilera era guía el dios Cupido y de la otra el Interés, aquél adornado de alas, arco, aljaba y saetas, éste vestido de ricas y diversas colores de oro y seda» (Quijote, II, 20). En el texto poético que pronuncian ambos, el Interés se declara más poderoso que el amor, según reflejan emblemas como el de Corrozet «Amour vaincu par argent» (HenkelSchöne, col. 1762).

Una amplia serie de motivos emblemáticos diseminados por los poemas amorosos de Cervantes muestran los efectos contradictorios y dolorosos del amor. La mayor parte podría relacionarse con los ámbitos del amor cortés marcados por la experiencia de la frustración y del sufrimiento; otros pertenecen al universo del neoplatonismo, influido sobre todo por las modulaciones garcilasianas.

Un elenco de los más importantes, que es imposible analizar individualmente, debería contemplar símbolos de frustración amorosa como la ninfa Eco, las espinas del amor, el veneno de la serpiente, el veneno de la adelfa, el laberinto, o el yugo insano de la esclavitud ${ }^{24}$. Todos son bien conocidos en los repertorios, aunque se apliquen a diversas intenciones, sin que falte entre ellas la expresión del amor, igual que en Cervantes.

23 HenKel-Schöne, col. 201. Ver también Horozco, libro I, fol. 32.

24 Eco, 1, 3 «en Eco amarga de cansado aliento» (ver HENKEL-SCHÖNE, col. 1034); espinas en flores y rosas, abrojos, 1, 10-12; 32, 86-88; 34, 416-17 (ver BORJA, 316-17, planta de cardos espinosos, glosada la imagen: «el que aquí sembrare deleites no espere coger sino trabajos y dolores con mucho acrecentamiento y abundancia, que es lo que se nos enseña con los cardos y espinas, pues tales son los gustos y deleites ilícitos de esta vida»; SAAVEDRA, empresa 34 rosal espinoso; HENKEL-SCHÖNE, cols. 295-96, 353 y ss., o en la 299 el emblema de Vaenius aplicado exactamente a nuestro caso del amor: «Armat spina rosa, mella tegunt apes», con la glosa "Suauem Amor (ecce) rosam dum deligit ungue rosetis, / a rigidis spinis saucia membra dolet. / Quod iuuat, exiguum; plus est laedit amantes, / Queque ferunt, multo spicula felle madent»; PIERO VALERIANO, fols. 399 y ss.); veneno de serpiente, 3, 5-6 (BORJA, 242-43; PIERIO VALERIANO, fols. 106-107); adelfa venenosa, 68, 9-10 (BORJA, 122-23; HENKEL-SCHÖNE, col. 342); laberinto, 26, 1-2; 34, 490-92 (HENKEL-SCHÖNE, cols. 1200-1202); yugo, 49, 6 «fiero yugo», 57, 8; 65, 19 «yugo insano"; 68, 38 (ver para emblemas con el yugo del amor HENKEL-SCHÖNE, col. 1439)... El yugo matrimonial, de distinto matiz, aparece en otras ocasiones (32, $118 ; 33,15-16,20 ; 57,8$; ver RIPA, II, 46-47, con el grabado que representa al matrimonio como un joven con el yugo al cuello, y la explicación correspondiente). 
Algunos pasajes muestran grados interesantes de elaboración, más allá del uso inmediato que estriba en las connotaciones emblemáticas habituales. Reparemos en el motivo de la serpiente, por ejemplo, en el poema 3, 1-6:

$$
\begin{aligned}
& \text { Blanda, suave, reposadamente, } \\
& \text { ingrato amor, me subjetaste el día } \\
& \text { que los cabellos de oro y bella frente } \\
& \text { miré del sol que al sol escurecía; } \\
& \text { tu tósigo cruel, cual de serpiente } \\
& \text { en las rubias madejas se escondía... }
\end{aligned}
$$

Cervantes parte del tópico el retrato femenino, con el cabello de oro, pero lo contamina poéticamente con otro procedente de un famoso texto virgiliano (Bucólica, 3, 93: «latet anguis in herba») de la sierpe o áspid oculto en las flores, que Garcilaso había usado espléndidamente en la Égloga III (vv. 129-132: "Estaba figurada la hermosa / Eurídice, en el blanco pie mordida / de la pequeña sierpe ponzoñosa, / entre la hierba y flores escondida»). La modificación cervantina es ingeniosa al identificar las hebras del cabello de la amada con el prado donde se oculta la serpiente, sin que podamos desechar ciertas connotaciones meduseas en esa cabellera serpentina. Por otra parte hay una emblematización en Ripa muy cercana a la idea del texto cervantino: la Traición se representa como una furia infernal pulcra y cuidadosamente vestida con una máscara que «tendrá muy rubios y rizados los cabellos, llevando en la cabeza un velo sutilísimo tras el cual se traslucen unas sierpes que conforman su verdadera cabellera»(II, 365).

El extremo más negativo del proceso amoroso lo constituyen los celos, proyectados a través de la imagen de las Harpías $(34,308)^{25}$, o de la morada de los celos (173), que es, en palabras de Bernat Vistarini ${ }^{26}$, «toda ella un emblema con su inscriptio en huesos humanos a la entrada»:

\footnotetext{
Yace donde el sol se pone, entre dos tajadas peñas, una entrada de un abismo, quiero decir, una cueva, profunda, lóbrega, escura [...]

Por las funestas paredes, por los resquicios y quiebras,
}

25 Ver para emblemas con HARPÍAS AlCIATO, 32; RIPA, II, 95-96; HENKEL-SCHÖNE, cols. 1635-36.

26 «Algunos motivos emblemáticos», p. 95, n. 20. 


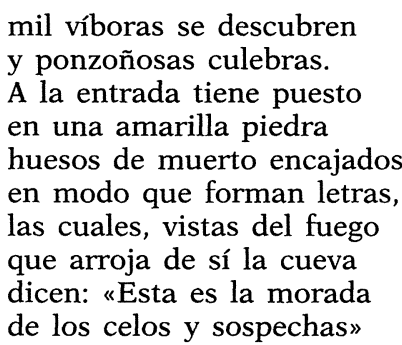

Los detalles definitorios de las víboras, el color amarillo o la escritura de huesos de muertos responden, claramente, a conceptos emblemáticos ${ }^{27}$.

Hay otras imágenes sólo inteligibles si recurrimos a este mundo simbólico: los múltiples cuidados del amor se expresan por medio del espejo roto $(3,25-30)$, emblema que en Saavedra Fajardo (empresa 33, león que se mira en espejo roto) enseña que «lo que representa el espejo en todo su espacio representa también después de quebrado en cada una de sus partes» y se aplica a una lección de constancia y fortaleza, como corresponde a su contexto.

La identificación del amor con una quimera es otro caso significativo de esta multiplicidad monstruosa de las preocupaciones y dolores de amor. En el poema 8, 10-11 se limita el locutor cervantino a mencionar la quimera como término metáforico, pero en el 140, 32 y ss. (cancioncilla de El celoso extremeño) elabora un retrato quimérico de la hermosa enajenada de amor, adaptado al caso:

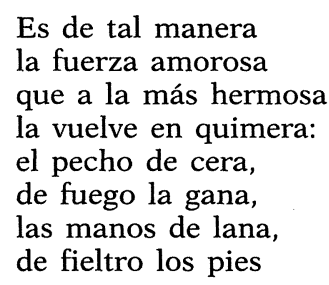

retrato grotesco que hay que relacionar con la figura de la quimera, monstruo que tenía, según Lucrecio y Homero, cabeza de león, vientre de cabra y cola de dragón (Ripa, II, 95; Alciato, 14 «Que con buen consejo y valor se vence a la Quimera, es decir, a los más fuertes y embusteros»).

27 Ya he comentado el motivo de las sierpes; el color amarillo es "contrario de la esperanza por el mismo respecto cuando esto que es verde se marchita y seca» (Horozco, libro I, fol. 101 r.). Para los huesos de muerto en emblemas diversos: HENKEL-SCHÖNE, cols. 1000-1001. 
El motivo más repetido es, como he indicado antes ${ }^{28}$, el del mar airado, símbolo del amor en este contexto, y de sus peligros difícilmente dominables: Amor es "turbado mar do no se ha visto calma» $(39,18)$, una tormenta cuyo único puerto seguro es la fe amorosa $(51,9-10)$, una implacable tormenta $(57,26)$, un mar de tormenta que jamás ve bonanza $(64,31-32)$, un "hirviente mar y golfo insano / donde tanto amenaza la tormenta» (80, 1-2), etc. Todo el soneto 53 (II Soneto de Silerio) estriba en esta alegoría:

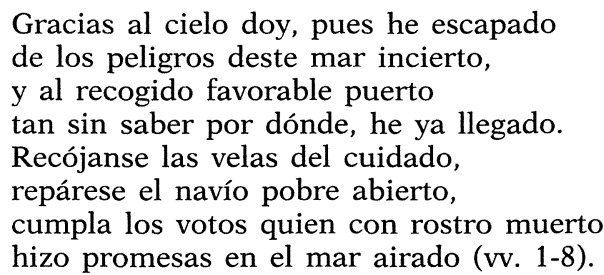

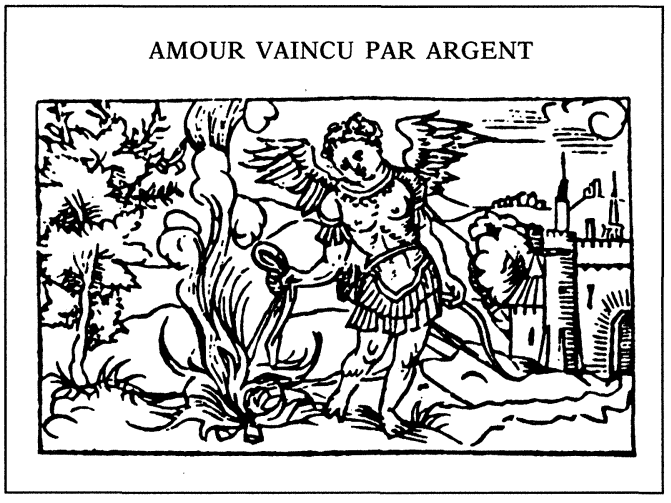

Amor vencido por el dinero (Corrozet).

Es también llamativa la acumulación de detalles emblemáticos en dos poemas claves, los núms. 39 y 40 que son sendas «definiciones de amor», una negativa, la otra positiva, en las que se enfrentan diversos elementos en serie: para la visión negativa Cupido tirano con su arco y flechas, el tempestuoso mar, Circe engañadora, yugo doblegador, rayo destructivo, cercado laberinto, gusano que fabrica su estancia...; para la visión positiva aduce sucesivamente la palma de victoria, el lince de aguda vista, flor (que crece entre espinas), hiedra, norte orientador, farol, sol que deshace las nieblas, escala que lleva al cielo, espejo que refleja liberal la naturaleza, Argos siempre vigilante... ${ }^{29}$.

28 Ver supra. Ahora acopio algunos ejemplos de la poesía cervantina. Añádanse a los citados otros casos en 30, 177; 37, 10-11 (raro caso de mar amoroso en calma); $104,12-14 ; 107,1-4 ; 126,6 ; 146 \ldots$

${ }_{29}$ La mayoría de estos emblemas han sido comentados o lo serán en lo que sigue; ver, no obstante, para Circe HENKEL-SCHÖNE, cols. 1694-95; gusano de seda que teje su propia cárcel HENKEL-SCHÖNE, cols. 915 y ss., HoROZco, Libro II, fols. 69 y 81 (con la glosa «De su propia sustancia aquel gusano / artífice ingenioso de la 
La técnica acumulativa refleja en su propia concentración la gran importancia conferida por Cervantes a estos elementos en la configuración de su discurso poético.

Terminemos, en fin, recordando los escasos ejemplos de sentido positivo que caracterizan, en algunos momentos más optimistas, al amor: apuntaré aquí la vid y el olmo (21, 9-10), expresión de unión indisoluble, que aparece en numerosos emblemas. Sobre el tratamiento del topos por parte de los clásicos latinos, véase Ripa, I, 134-135: «Benevolencia y unión matrimonial», de donde proceden los siguientes textos: "Ulmus amat vites, vitis no deserit ulmum» (Ovidio); "Ut vidua in nudo vitis quae nascitur arvo nunquam se extollit [...] At si forte eadem est ulmo coniucta marito» (Catulo); «Amano ancora gli arbori, verder puoi con quanto afetto et con quanti iterati abbracciamenti la vite s'avviticchia al suo marito" (Tasso), etc.

Con relativa frecuencia se presenta en los emblemas la vid enlazada a un olmo seco, para comunicar el mensaje de la amistad que dura aun después de la muerte: así en Alciato (emblema 159) o en las Empresas morales de Juan de Borja (115) cuya segunda parte vuelve al olmo y la vid como ejemplo de la amistad virtuosa que «multiplica el fruto de sus buenas obras» (290-291).

Es un topos, por otro lado, ya estudiado ${ }^{30}$ y del que no alargaré el comentario.

\subsubsection{La amada}

En la figuración de la amada se distingue en primer lugar un atisbo de la descriptio femenina petrarquista ${ }^{31}$, con los cabellos de oro $(3,3-4 ;)$, dientes como perlas entre grana $(3,46)$, ojos luminosos $(4,17)$, etc., que no atrae demasiado la atención de Cervantes, cuya poesía es muy poco plástica o sensorial ${ }^{32}$. El retrato pe-

seda / va tejiendo un capullo do se enreda / y muere en cárcel hecha por su mano"); Argos, Horozco, libro II, fol. 25; escala del cielo (relacionado con el motivo de la escala de Jacob) HENKEL-SchÖNE, col. 1203 y Horozco, Libro II, fol. 51; Horozco en el libro I, capítulo 2 dedicado a la "Primer insignia o empresa que hubo en el mundo y de algunos Hieroglyphicos que en la Sagrada Escritura se hallan», dice, considerando a la escala de Jacob como uno de los primeros jeroglíficos: "La escala de Jacob [significa] la comunicación de Dios y de los hombres mediante la Encarnación de su Hijo». La visión de Jacob está relatada en el Génesis, 28, 12. Para espejos ver HENKEL-SCHÖNE, cols. 1346 y ss.; para el sol, la hiedra y otros ver infra.

30 Ver P. DEMETZ, "The Elm and the Vine: Notes Toward the History of a Marriage Topos», y A. EgIDo, "Variaciones sobre la vid y el olmo en la poesía de Quevedo".

31 Ver para este repertorio M. P. MANERO, Imágenes petrarquistas.

32 Nótese que el emblema, tan usado por Cervantes, es un género visual, sí, pero sometido siempre a una operación de exégesis intelectual. 
trarquista se inscribe en una concepción neoplatónica del amor, según la cual la belleza corporal es imagen de la belleza absoluta de la divinidad: de ahí que reaparezca a menudo el motivo del cuerpo como velo o cárcel que aleja del mundo perfecto celestial ${ }^{33}$.

En este marco hay que colocar una de las imágenes principales, muy tópica por otro lado, la de la amada como sol o fuente de luz $(3,3-4 ; 14,76 ; 15,12 ; 19,9-10 ; 29,1-2 ; 31,54 ; 41,11-12 \ldots)$ cuya frecuencia hace innecesaria mayor documentación.

Lo que más interesa a los efectos emblemáticos es la ponderación de la amada cruel o desdeñosa, cuya dureza se pondera recurriendo a comparaciones con piedras o materiales preciosos, en contextos que privilegian sus connotaciones negativas ${ }^{34}$ : la amada es dura como el diamante, peña, acero o mármol $(1,23 ; 12,73-74$; 14,$77 ; 21,4 ; 34,134$ y ss.; 79, 89-91). Una imagen más elaborada es la de la estatua de piedra:

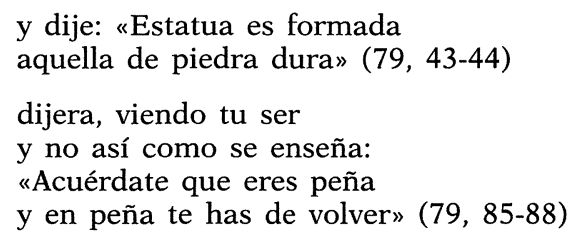

En los libros de emblemas se recoge con cierta frecuencia el caso de Níobe (más que el de Anajárete), convertida en peña por su soberbia y condenada a la insensibilidad total: así en Alciato (emblema 67), o en Horozco, libro III, fol. 133, con grabado de estatua de piedra y la glosa:

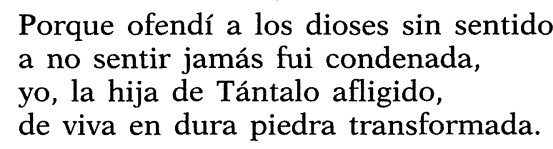

Una categoría importante procede de los bestiarios fabulosos, componente fundamental del universo emblemático. La amada será tigre, leona, basilisco, culebra, víbora, o sirena, entre otras referencias; los ejemplos abundan:

Tan terrible y rigurosa

como víbora pisada $(12,41-42)$

fiera culebra

del crudo desdén $(34,77-78)$

33 El cuerpo como velo o cárcel aparece en los poemas $4,1-3 ; 32,25 ; 34,153 \ldots$

34 Ver HENKEL-SCHÖNE, cols. 85 y ss. 
mejor la podré llamar

sirena falsa del mar $(65,37-38)$

que un basilisco se mira

en ti, que mata mirando $(132,13-14)$

y nos matas si nos miras

y nos encantas si cantas (132, 43-44)

como leona de Orán

o como tigre de Ocaña $(133,7-8)$

la sirena que encanta

y adormece a los más apercebidos $(136,35-36)$

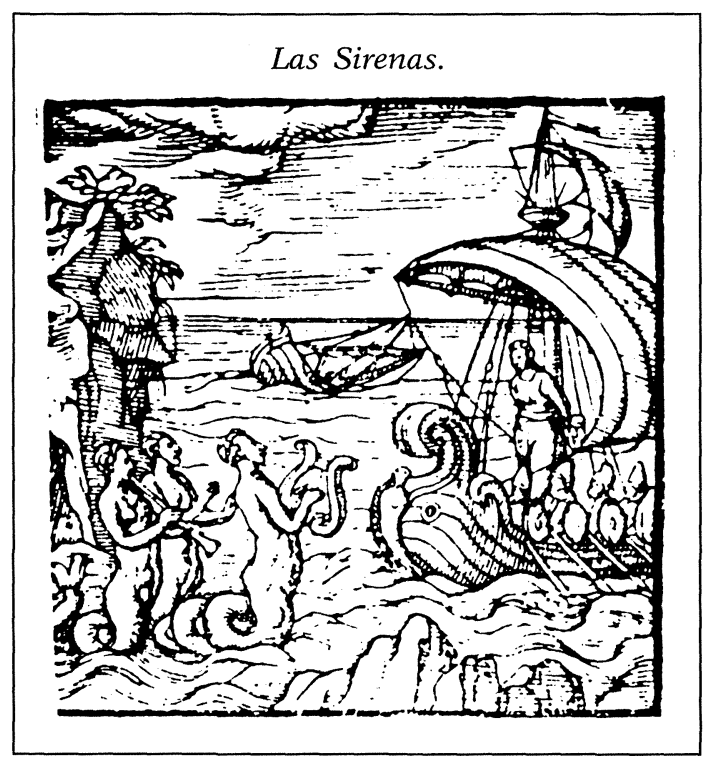

Sirenas (Alciato).

Todos estos símbolos animales son bien conocidos y su filiación emblemática intensísima.

De todas las sierpes venenosas, culebras, áspides, etc., el basilisco es la más mortífera: monstruo fabuloso con alas de pájaro, cola de dragón y cabeza de gallo, producto de huevo de gallo incubado por una serpiente $y$ cuya mirada $y$ aliento causan muerte instantánea. Se llama basilisco (de basileus, rey), rey de las serpientes, por la cresta que corona su cabeza ${ }^{35}$. Tigres y leones son emblemas de la ira, la crueldad y la violencia: Villava (II, empresa 8) «Del airado» presenta una tigre de Hircania atacando a un caballo: «la pasión de la ira [...] San Crisóstomo dice que es una fiera, nacida en nuestro pecho y cebada en nuestra propia sangre, y que se admira de que los príncipes y señores se precien de tener domada una tigre y un león y no domen esta fiera». Numerosos emblemas con leones representan la crueldad y la ira, entre las posibilidades sig-

35 Ver. I. MALAXEChEVERría, Bestiario medieval, 160-61: «Este animal representa al diablo, al mismo Satanás que se escondió en el Paraíso". Para ejemplos de basiliscos y otras sierpes venenosas en emblemas ver BORJA, 352; VILLAVA, II, 47; VALERIANO, fol. 105; HENKEL-SCHÖNE, cols. 627 y ss. 
nificativas del león (ver Valeriano, fols. 6-7; Henkel-Schöne, cols. 370 y ss., especialmente 374 ).

La sirena pertenece ya al terreno mitológico. Son seres con cabeza y busto de mujer, y cuerpo de pez o pájaro, de canto tan atractivo que era imposible a los navegantes resistirse a su tentación; San Isidoro las describe en sus Etimologías, XI, 3, 30: "A las sirenas que eran tres, se las imagina con un cuerpo mitad doncella, mitad pájaro, dotadas de alas y uñas [...] con su canto atraían a los navegantes fascinados que eran arrastrados al naufragio». Alciato (emblema 115) las representa con la cuerpo mitad pez serpentino y tocando la lira, «mujer seductora que acaba en oscuro pez, como muchos monstruos que trae consigo el deseo" y para Horozco (libro II, emblema 30) son símbolo del vicio que empieza en forma agradable y termina en monstruo: «Y para recuerdo desto se nos ofreció en la presente emblema figurar una serena en el mar; de quien fingieron Homero y los demás que con su canto y hermosura encantaban las gentes para destruición dellas, siendo que se monstraba de parecer hermoso y apacible y lo demás que se encubría de fiero monstruo" ${ }^{36}$.

Otras tres referencias bestiarias expresan una actitud amorosa distinta a las anteriores: la amada se compara a una paloma sin hiel $(133,5)$, al ave fénix por ser única y sola, sin par $(41,36)$ y a la mariposa que se quema en el fuego (del amor: 140, 23-26).

La carencia de hiel de la paloma la consigna Covarrubias, en el Tesoro de la lengua castellana. Núñez de Cepeda (empresa XIX) escribe sobre la candidez y sencillez de la paloma, y García Mahiques ${ }^{37}$ señala que «la paloma posee un bagaje simbólico positivo en todos sus aspectos y son también innumerables los conceptos formados por medio de su imagen", recordando por ejemplo, que en los Commentaria symbolica de A. Brixiano aparece con noventa y dos significaciones diferentes. Ferrer de Valdecebro (Gobierno general, moral y político hallado en las aves, libro XVII, cap. LXX) pondera: «Cándido y sencillo pájaro y el más venturoso que puebla ciudadano la región del viento es la paloma, pues mereció que la persona tercera de la Trinidad Santísima, el divino espíritu de amor, apareciese en su forma sobre las corrientes claras y cristalinas del Jordán [...] Tiene también de buena dicha el que la Madre del Unigénito Verbo encarnado, María Santísima, se nombre con nombre de paloma en los Cantares» ${ }^{38}$. Como símbolo de paz lleva la

36 Otras sirenas en SAAVEdRA FAJARDo, empresa 78; CAMERARIUS, LXIII de Symbolorum... aquatilibus; HENKEL-SCHÖNE, cols. 1697-98.

37 Empresas sacras de Núñez de Cepeda, 94-95.

38 Ver infra las referencias marianas de la Canción a la Virgen de Guadalupe. 
oliva en el pico, significando a Cristo pacífico en la empresa X (parte I) de Villava (Empresas espirituales), en tanto carece Cristo de la hiel de la venganza, empresa que es muy semejante al emblema de Camerarius "Divinae nuncia pacis» ${ }^{39}$.

La mariposa que se quema en el fuego es símbolo amoroso en Vaenius (Henkel-Schöne, col. 911) con el mote «Brevis et damnosa voluptas»; con otros sentidos pero con representaciones semejantes se puede hallar en Borja, 66-67, aplicable en este caso también al amor (y a otras situaciones en que la razón se deja llevar del apetito): «el que [...] es llevado por este deseo contra lo que entiende que le conviene puede lo dar a entender con esta empresa de la mariposa que se quema con la letra Fugienda peto, que quiere decir "Busco lo que huir debría", porque lo mismo le acontece al que no siguiendo el partido justo de la razón consiente en la rebelión de los apetitos».

Para los motivos referentes al ave fénix remito al apartado siguiente.

\subsubsection{El amante}

En correspondencia con el retrato de la amada cruel y desdeñosa predominante en los locutores cervantinos, surge el del amante caracterizado por el dolor amoroso y por la firmeza ante ese sufrimiento.

La perspectiva del emisor masculino (la más abundante en el corpus examinado) privilegia el rasgo de la fe y constancia en el amante ${ }^{40}$ frente a la traición y volubilidad de las amadas. La recurrencia a motivos emblemáticos de la mitología y bestiario permiten expresar, como en los apartados anteriores, estos rasgos.

En torno al amante y la historia de sus cuidados se concentran los más intensos motivos mitológicos de héroes condenados y ejemplos de frustración.

El tema de Ícaro, derribado al derretirse sus alas de cera por acercarse demasiado al sol, es uno de lo más claros en su capacidad de expresar el amante que aspira a una amada (metaforizada en sol, como se ha visto) demasiado alta para sus merecimientos o posibilidades, lo que desemboca en la caída; caída, no obstante, que se ve como un glorioso fracaso (tema que en la poesía de Villamediana será crucial y que se hace tópico en la poesía del Siglo de

39 Symbolorum... ex volatilibus, en HENKEL-ScHÖNE, col. 857.

40 Para completar la caracterización del amante en cuanto a sus dimensiones petrarquistas ver M. P. MANERO, "Aproximaciones al estudio del petrarquismo". 
Oro). Ícaro es término de comparación explícito o implícito en muchos poemas cervantinos:

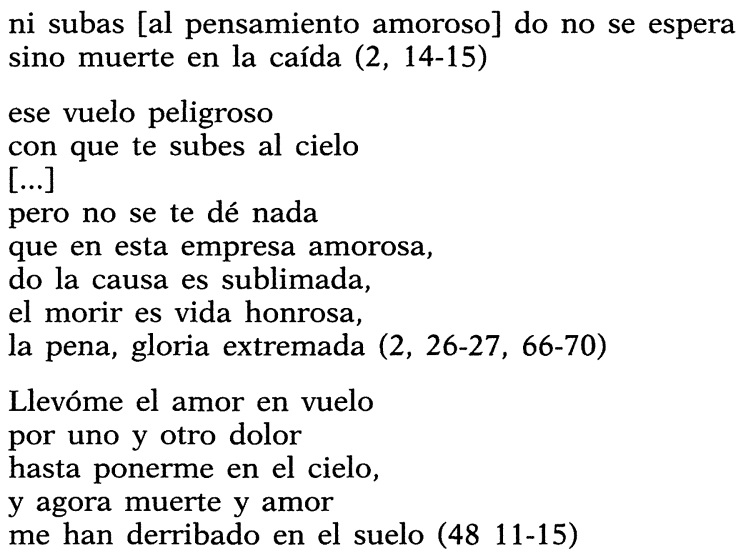

Aplicado a los astrólogos representa Alciato (103) a Ícaro derribado desde el cielo; con lecciones semejantes contra temerarios y atrevidos traen emblemas los libros de Corrozet, Reisnerius y Vaenius (Henkel-Schöne, col. 1617) ${ }^{41}$.

Tántalo, condenado a sufrir eternamente hambre y sed sumergido en la laguna con el ramo de frutas al alcance de la mano es otro de los modelos de representación del amante: es el subyacente a una queja como la de Crisio en una égloga de La Galatea:

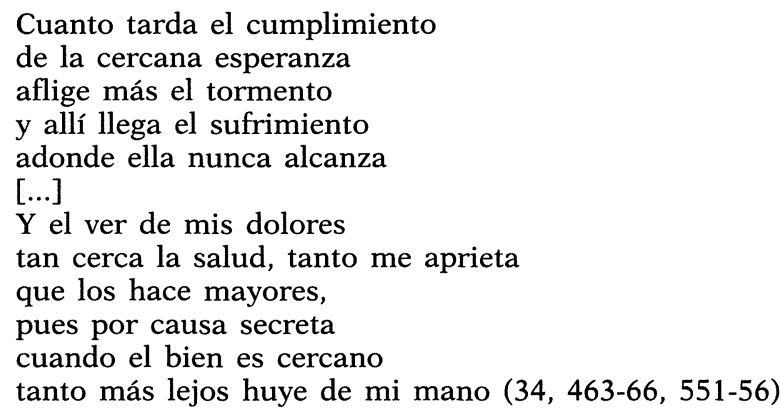

En Alciato (emblema 84), Borja (196), Henkel-Schöne (col. 1655, con varios ejemplos) se localizan parejas representaciones de Tántalo, al cual describe Homero en La Odisea (XI, 582-92) sumergido hasta el mentón en las aguas de un lago penando de sed, que

${ }^{41}$ Sobre el tema de Ícaro en la poesía del Siglo de Oro ver TURNER, The Myth of Icarus. 
en vano quería saciar, pues cada vez que se agachaba a beber con ansia ardorosa, se escapaba el agua que un dios desecaba, y cuando alargaba sus manos para tomar las frutas que corpulentos frutales tendían hacia su frente, un viento veloz los alzaba a las nubes sombrías alejándolos de él.

La Canción de Grisóstomo en el Quijote es el texto con mayor concentración de estos ejemplos mitológicos:

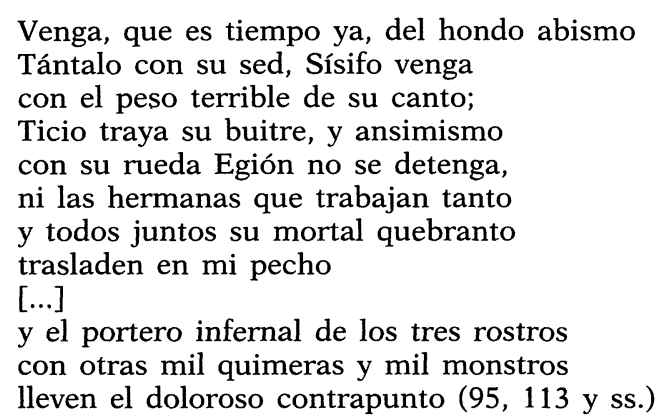

De todos ellos, Ticio con el hígado devorado eternamente por un buitre, Ixión torturado en su rueda, Sísifo empujando su piedra para que vuelva a rodar desde la cumbre, las Danaides (las «hermanas que trabajan tanto») condenadas a llenar un tonel del que se escapa el agua sin cesar, el perro Cerbero de las tres cabezas o la quimera ya anotada anteriormente, hay abundantes emblemas ${ }^{42}$; el discurso lamentativo de Grisóstomo se coloca en este territorio emblemático de una manera decidida.

Tanto sufrimiento puede acarrear la muerte al dolido enamorado. Aparte de las menciones trivializadas por el tópico, la emblemática puede ofrecer materiales algo más complejos a los locutores líricos, como Damón, quien compara la vida del amante a una vida cuasi ficticia que aparece más viva cuando está ya prácticamente muerta, paradoja que se ilustra con el ejemplo de la vela "que cuando muere, más su luz aviva» $(14,25-30)$, lo que es ni más ni menos que un emblema recogido por Borja (174-75), quien explica el grabado de una vela con el mote «Breviora lucidiora»: "se ve que cuanto más cerca está a acabarse una vela tanto mayor luz y claridad da». Obviamente la aplicación del texto de Cervantes es distinta a la moralización de Borja, pero la idea y la concepción expresiva son exactas.

42 Ver solamente HENKEL-SCHÖNE, cols. 1658-65; BORJA, 104-105; RIPA, II, 97, Horozco, libro III, 115... En esos repertorios se hallarán suficientes ejemplos de todos los citados. 
El rasgo que con más frecuencia se atribuye a sí mismo este amante cervantino es el de la firmeza. Si se recuerda la importancia del mar y la tempestad como metáfora de los riesgos y peligros del amor, se comprenderá la coherencia de la otra imagen emblemática que ahora se le contrapone como símbolo del amante: la roca en medio de las olas combatida, pero firme. Así es la fe de Silerio «más firme y contrastada / que roca en medio de la mar airada» (26, 31-32); así está el firme pecho de Lauso frente a los desdenes de Filis, "cual firme roca contra el mar» $(58,96)$; la pastora cruel

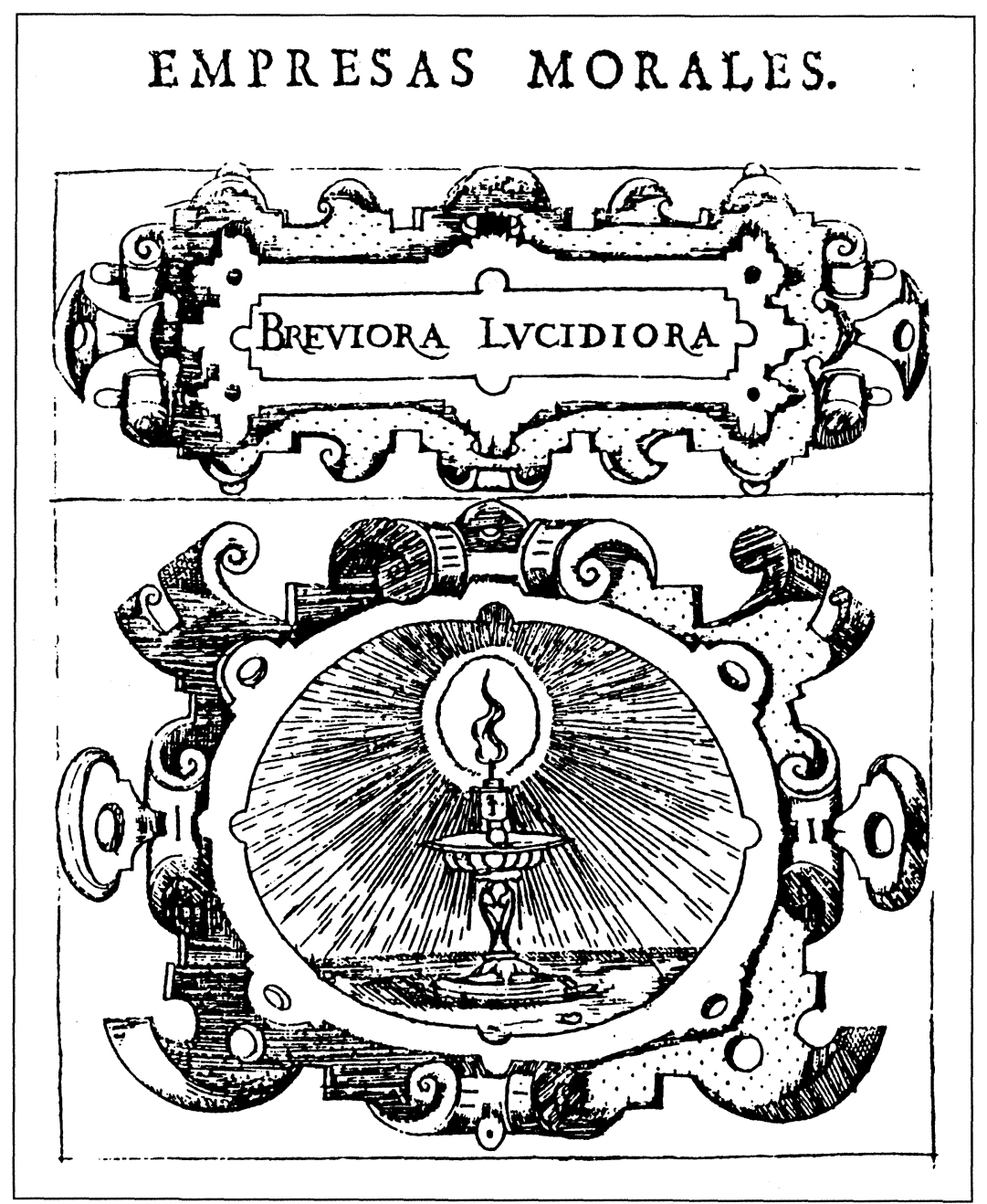

La luz brilla más antes de morir (Borja). 
que frustra a Artemidoro, en cambio, se muestra "no firme al mar $\mathrm{y}$ a los vientos / como bien fundada roca» (12, 39-40), etc.

De nuevo una ilustración de Borja (34-35) es la más cercana a la concepción cervantina: un peñón en el mar alterado con el mote «Ferendo vincam», enseña que frente a los trabajos el mejor medio «es la firmeza y constancia de ánimo, para sufriendo vencerlos, lo que significa esta empresa del peñasco, en que la mar rompe, con la letra Ferendo vincam, que quiere decir "Sufriendo venceré". Porque así como el peñasco sufriendo los golpes de las olas en la tormenta, con su firmeza las deshace y vence, de la misma manera el

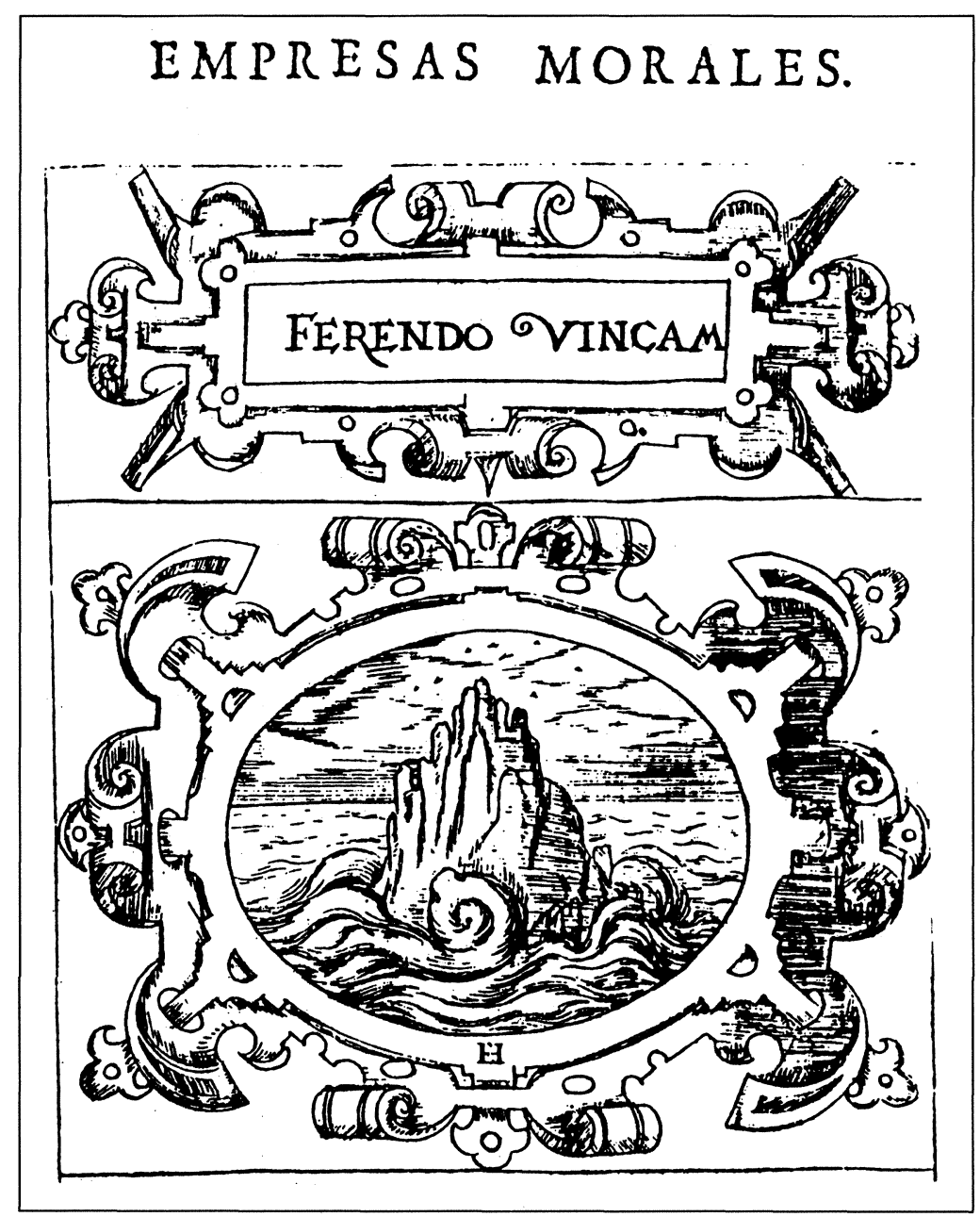

El peñasco incólume (Borja). 
que tuviere firmeza y valor para sufrir los trabajos por grandes que sean, si él de su propia voluntad no se les rindiere, al cabo con paciencia los vencerá».

Aún aparece otro símbolo de resistencia extraído de los emblemas, el avestruz capaz de digerir el hierro, como el amante digiere los desdenes $(189,13-14$ : «Digiero ya tus desdenes / como el avestruz el hierro") ${ }^{43}$.

Del mismo modo que la roca resistente al mar constituye un emblema coherente con la imagen contrapuesta del amor como piélago tempestuoso, Cervantes elige un nuevo sistema coherente con la otra expresión privilegiada del amor, el fuego. En este terreno no es de extrañar la recurrencia al bestiario ígneo, formado esencialmente por la mariposa, el ave fénix y la salamandra.

Sobre el fénix y su resurrección de las cenizas en que él mismo se quema, los testimonios serían innumerables; basten algunas líneas de Covarrubias (Tesoro):

Fénix. Dicen ser una singular ave que nace en el oriente, celebrada por todo el mundo; críase en la felice Arabia [...] y vive seiscientos y sesenta años. Plinio, hablando della, dice así, lib. 10, cap. 2: Et ante omnes nobilem Arabiae phoenicem [...] vivere annos DCLX, senescentem casia, thurisque surculis construere nidum, replere odoribus et super emori. Ex ossibus inde et medullis eius nasci primo ceu vermiculum, inde fieri pullum [...] Todo lo que la antigüedad ha dicho de la fénix [...] lo refiere Plinio en el lugar alegado [...] muchos han formado jeroglíficos de la fénix aplicándolos a la resurrección de Nuestro Redentor.

Malaxecheverría, Bestiario medieval, 120-127, por ejemplo, 123 124 recoge otros textos: "cuando la vejez le agobia, recoge ramas de plantas aromáticas y se construye una hoguera; luego, vuelto hacia el sol, aviva el fuego agitando sus alas, y a continuación renace de sus cenizas». Baltasar de Vitoria traduce a Ovidio en Teatro de los dioses de la gentilidad, I, 611: «En la más alta cima de una palma [...] / Su vida se ha entre olores fenecido, / De suerte fenecido, que del fuego / Otro pequeño Fénix nace luego».

Ferrer de Valdecebro, en el libro que dedica a las aves (ver pp. 90-98), argumenta en favor de la existencia del ave fénix, siguiendo «el corriente de los más santos filósofos y escritores», y comenta el sentido de resurrección de la carne en el capítulo XXXV.

Sobre el ave fénix traen emblemas Camerarius, Piero Valeriano, Horapolo... ${ }^{44}$.

\footnotetext{
43 Para el avestruz capaz de digerir el hierro: BORJA, 178-79; HENKEL-SCHÖNE, cols. 806-7.

44 CAMERARIUS, Symbolorum et emblematum ex volatilibus; VALERIANo, Hieroglyphica, libro XX, 144; HORAPOLO, Hieroglyphica, 224. Ver también HENKEL-SCHÖNE, cols. 795-96.
} 


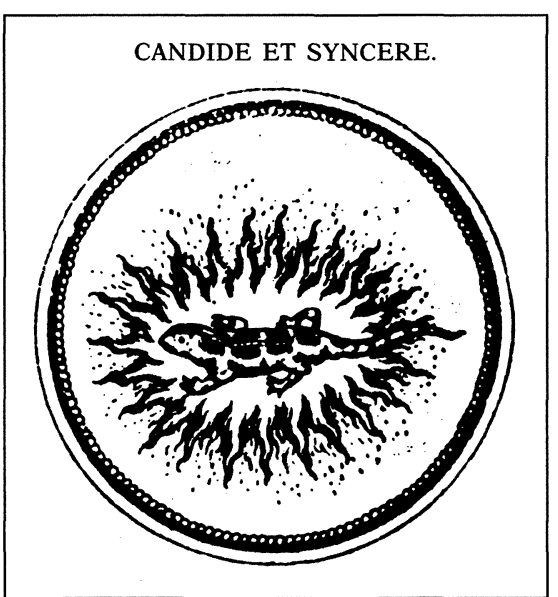

Salamandra en el fuego (Camerarius).

La salamandra se hace fácilmente símbolo amoroso por la capacidad que se le atribuía de poder vivir en el fuego. Villava (II, empresa 49) «In vanum flamma laborat» trae a la salamandra como símbolo del obstinado, pero en el libro XVI de Valeriano, entre otras significaciones, la salamandra, simboliza al "Amator» (Hieroglyphica, fol. 120r.): "Sunt qui per huiusmodi speciem, per salamandram quippe in igne positam amatorem ostentent, quod amore ex igne significari apud omnes vulgatum sit [...] et ardere se amantes omnes profiteantur». El mismo valor tiene en otro emblema de Vaenius (HenkelSchöne, cols. 739-40) «Mea vita per ignem».

Ambos animales aparecen unidos en la imaginería amorosa cervantina, reforzando sus significaciones y complementando sus matices. Erastro se compara con la salamandra, de manera implícita, y con el fénix explícitamente, en un mismo pasaje:

$$
\begin{aligned}
& \text { En esta vista reposa } \\
& \text { mi alma, y halla sosiego } \\
& \text { y viven en el vivo fuego } \\
& \text { de su luz pura, hermosa. } \\
& \text { Y hace amor tan alta prueba } \\
& \text { con ella, que en esta llama } \\
& \text { a dulce vida me llama } \\
& \text { y cual fénix la renueva }(29,33-40)
\end{aligned}
$$

Fénix y salamandra vuelven a mencionarse juntos en el 30, 169-74:

$$
\begin{aligned}
& \text { En el fuego de amor puro me avivo } \\
& \text { y me deshago, pues cual fénix, luego } \\
& \text { de la muerte de amor vida rescibo. } \\
& \text { En fe desta mi fe te pido y ruego } \\
& \text { solo que creas, Nísida, que es cierto } \\
& \text { que vivo ardiendo en amoroso fuego. }
\end{aligned}
$$

La mariposa era ejemplo de la mujer enamorada también en un pasaje de El celoso extremeño que he comentado antes, a donde remito para el símbolo, que se aplica el amante en el poema 189, 11-12 ("como simple mariposa / por lo que me mata muero»). 
Fuera ya del bestiario se localiza otro motivo emblemático, el del bivium, interesante por su adaptación secularizada al terreno amoroso, en algunos poemas como el 51,6 y sobre todo el 30 , 100 y ss.

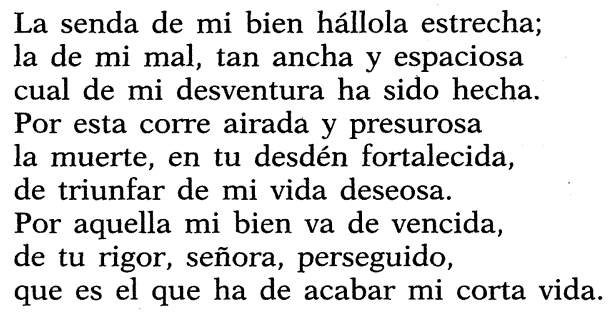

El bivium (dos sendas) simbolizado igualmente en la $\mathrm{Y}$ pitagórica, aparece también en el Evangelio: «Intrate per angustam portam, quia lata porta et spatiosa via est quae ducit ad perditionem, et multi sunt qui intrant per eam. Quam angusta porta et arcta via esta quae ducit ad vitam, et pauci sunt qui inveniunt eam» (Mateo, 7, 13-14). En la mitología Hércules debió elegir entre dos caminos, el estrecho de la virtud y el ancho del vicio: "siendo Hércules mancebo, llegó por un camino adonde se repartía en dos, y que el de la mano derecha era muy áspero y estrecho, y se llamaba de la virtud, y el de la mano izquierda muy ancho y llano y andadero, era el de los vicios y pecados» (P. Pineda, Agricultura cristiana). Quevedo, en los Sueños, «veo, cosa digna de admiración, dos sendas que nacían de un mismo lugar, y una se iba apartando de la otra como que huyesen de acompañarse. Era la de mano derecha tan angosta que no admite encarecimiento, y estaba, de la poca gente que por ella iba, llena de abrojos y asperezas y malos pasos» ${ }^{45}$.

\subsection{La Fama. El poeta laureado}

La preocupación de Cervantes por el oficio poético y la gloria literaria se rastrea en la fuerte presencia de este tema en su corpus, responsable a su vez de un conjunto de emblemas caracterís-

45 Ver ed. de I. ARellano, 172-173. Ver SuÁREZ DE FigueroA, Pasajero, 649: «no es de maravillar que no pase a la senda áspera y angosta de la virtud quien en su mocedad siguió el ancho camino de los vicios». Y GRACIÁn, Criticón, I, 174: "Así iban confiriendo cuando llegaron a aquella tan famosa encrucijada donde se divide el camino y se diferencia el vivir», con la documentada nota de Romera Navarro. Representaciones emblemáticas en HENKEL-SCHÖNE, cols. 1294-95. 
ticos. Si dejamos aparte la gran cantidad de menciones bastante lexicalizadas de la palma o el laurel, en diversos contextos, siempre símbolos de victoria o reconocimiento del valor o la fe amoro$\mathrm{sa}^{46}$, la mayor cantidad corresponde a la exaltación de los poetas y la poesía, especialmente en el poema 59, Canto de Calíope.

Antes de revisarlos conviene reparar en la Fama, como presencia general, distribuidora o heraldo de los triunfos.

En los poemas de Cervantes aparece la iconografía básica de la Fama, pregonera y parlera, con alas y ojos múltiples, que escribe en láminas de bronce o mármol y se acompaña de una trompeta $(48,21$ y ss.; $58,101-102 ; 62,16 ; 171,1-3,12-14 ; 181,9,11$; $185,12-13)$ :

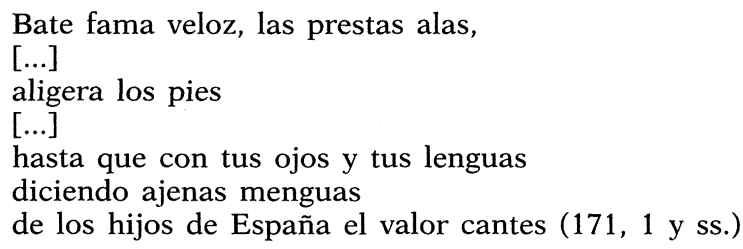

Cesare Ripa (I, 395-96) proporciona detalles oportunos: "Mujer vestida con sutil y sucinto velo, [... ] que aparece corriendo con ligereza. Tiene dos grandes alas, yendo toda emplumada, poniéndose por todos lados tantos ojos como plumas tiene y junto a ellos otras tantas bocas y otras muchas orejas. Sostendrá con la diestra una trompa». El emblema de Hadrianus Junius que recogen Henkel-Schöne (col. 1536) es perfectamente ilustrativo con su Fama, dedi-

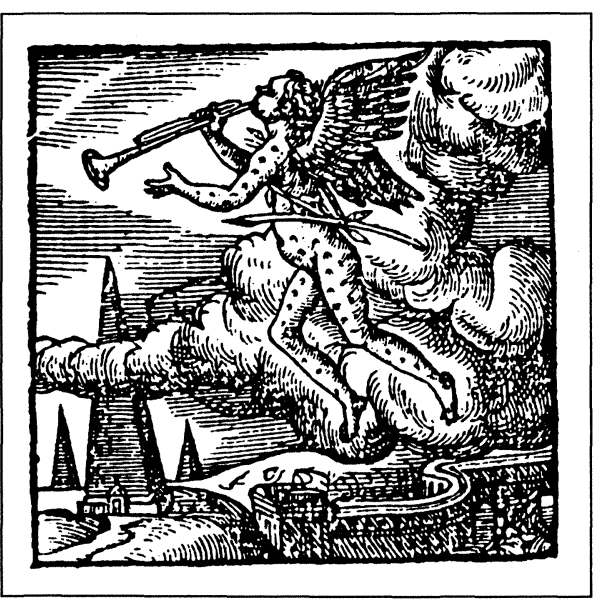

La Fama (Junius). cada a Jacobo Blondelio, «Oculata, pennis fulta, sublimem vehens / Calamum aurea inter astra Fama collocat».

46 Ver, entre otros, los poemas 30,$67 ; 34,672-73 ; 37,12 ; 44,51 ; 48,69 ; 78,29$; 95,$96 ; 117,16 ; 144,8 ; 157,5,14 ; 170,12 ; 175,8 ; 184,78 \ldots$ Para abundantes ejemplos emblemáticos BORJA, 222-23; VALERIANO, fols. 369-70; HENKEL-SCHÖNE, cols. 192 y ss., etc. 
Respecto a los símbolos de triunfo poético destacan los de las plantas y, de nuevo, los bestiarios.

En el citado Canto a Calíope se atribuyen a los distintos poetas elogiados coronas de laurel, hiedra, oliva y encina. Son todas símbolos de triunfo, de gloria poética (el laurel atribuido a Apolo, dios de la poesía; la hiedra siempre verde; la encina símbolo de fortaleza; la oliva de suavidad y paz...). Sería largo de ejemplificar con textos de los repertorios emblemáticos todos estos valores, que fácilmente se documentan ${ }^{47}$.

Más interés tienen tres emblemas animales. El cisne es el más tópico. Aparece en el poema 187, 9 en elogio al ingenio del conde de Saldaña. Es el estandarte de los buenos poetas en la guerra del Viaje del Parnaso, y como recuerda Aurora Egido, da pie a la escritura del tratado de Carballo Cisne de Apolo. Su sentido es muy conocido y no requiere mayores comentarios ${ }^{48}$.

La aplicación del águila al elogio de don Diego de Aguilar no se capta del todo si sólo se repara en el juego onomástico, primer nivel de ingenio explotado por Cervantes en este pasaje:

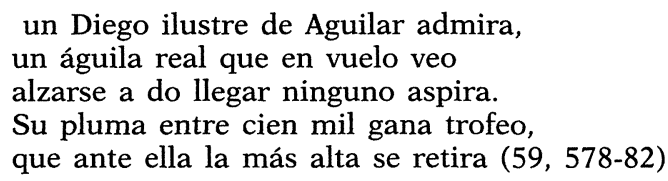

El juego va más allá también de la dilogía en pluma (de águila/ instrumento para escribir, metonimia del oficio poético). El hecho de que todas las otras plumas se retiren ante la de Aguilar, es decir, ante la del águila, tiene conexiones emblemáticas que aclaran el sentido: según explica, por ejemplo, Saavedra (empresa 92) con las alas del águila que destruyen a otras plumas «aun las plumas de las aves peligran arrimadas a las del águila, porque estas las roen y destruyen».

Otro juego onomástico permite elogiar al doctor Falcón (801-804) que remonta su vuelo más alto aún que el águila. Pero de nuevo la alusión hay que completarla recurriendo a los emblemas, en este caso concretamente al 139 de Alciato «Imparilitas», que puede ser la fuente de inspiración de la referencia cervantina ${ }^{49}$. Alciato repre-

47 HENKEL-SCHÖNE, cols. 202 y ss., para el laurel; 207 y 275 para la hiedra; 210 , 219 y ss. para la encina; Alciato, emblema 210, BORJA, 2-3 y VALERIANO, fols. 372 (laurel); VALERIANO, fol. 377 (hiedra); Alciato, emblemas 42 y 199 (encina), etc.

48 Para el cisne, símbolo de los poetas: Alciato, 183; VAlERIANO, fols. 164-65, HENKEL-SCHÖNE, col. 814...

49 BERNAT, "Algunos motivos emblemáticos», 89-90, pone este emblema de Alciato en relación con la imagen de los "cernícalos lagartijeros" del Viaje del 


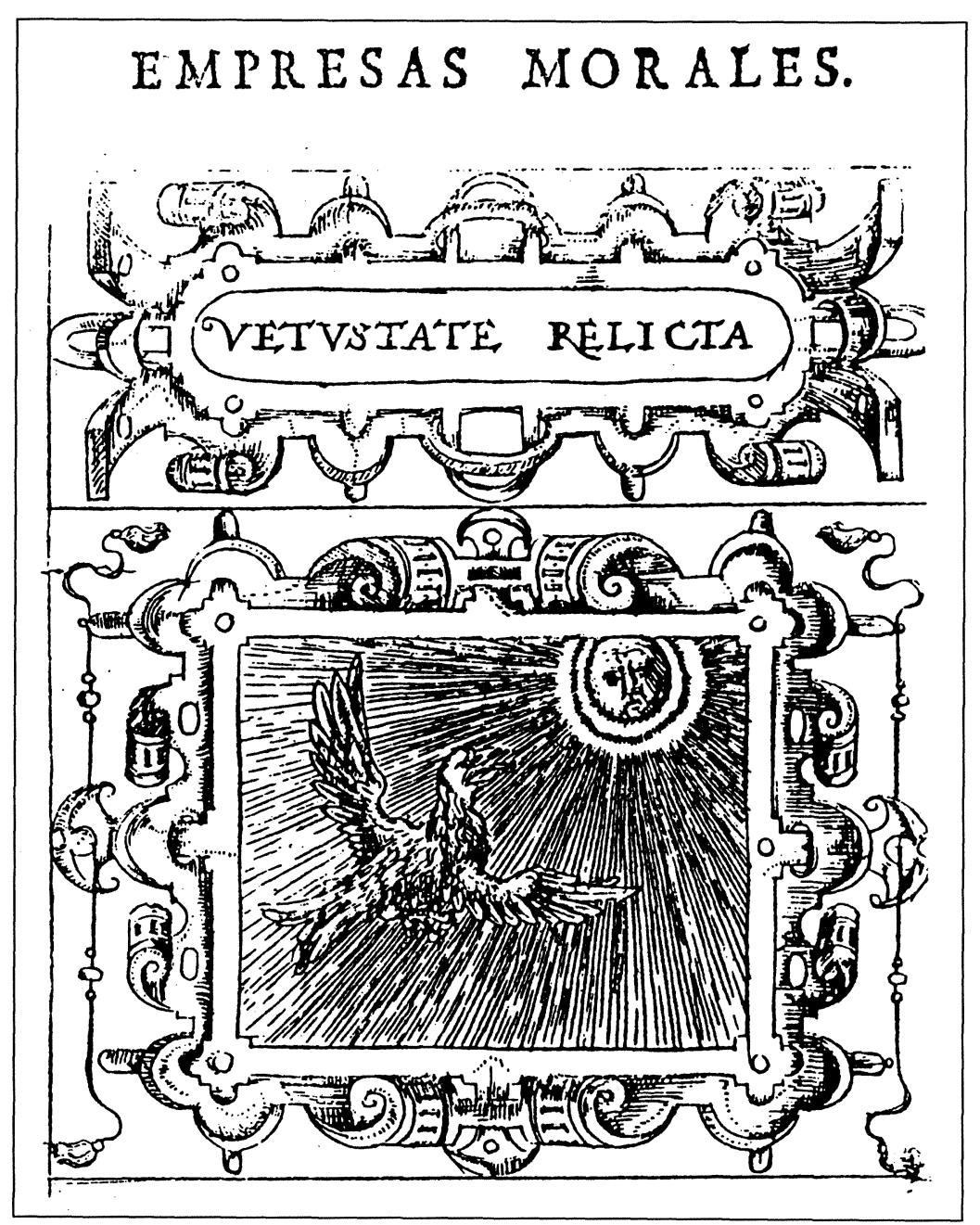

El águila rejuvenece al sol (Borja).

senta al halcón volando muy alto, mientras el grajo, el ganso y el ánade pacen en el suelo, y lo aplica al caso del poeta Píndaro que canta por sobre los cielos, frente al mediocre Baquílides que sólo sabe reptar por la tierra. La aplicación poética del emblema, ampliada en el comentario de Diego López a la diferencia de los ingenios, la acerca extraordinariamente al texto cervantino, que inserta

Parnaso. En este otro texto que cito creo que la cercanía es ya mucho más estrecha y me inclinaría a pensar en una conexión directa. 
el motivo en un juego de ingenio con el nombre, que supone además una agudeza de proporción en términos de Gracián (Agudeza $y$ arte de ingenio).

\subsection{Emblemas en poemas morales y sacros}

El ámbito de la moralización y el simbolismo propio de los emblemas hacen que el territorio de la poesía moral y sacra sea uno de los más aptos para la integración de este tipo de materiales. La mayoría de las referencias que localizamos en este sector del corpus han sido ya comentadas en otros contextos: ahora el contexto moralizante de un poema como el 38 centrado en el tema del menosprecio de corte, confiere precisos sentidos a figuras ya analizadas como el pensamiento vano o la vana imaginación $(38,1-3)$, las sirenas encantadoras (vv. 9-11), o el golfo insano del mar de las pretensiones cortesanas (9-11). En la Epístola a Mateo Vázquez (159) se insiste en los motivos de la Fortuna (vv. 37-38) y del bivium, ahora en preciso sentido moral, más habitual en los repertorios (vv. 85 y ss.).

Un nuevo emblema, que hasta ahora no había sido comentado, y que es esencial en la pintura de la corte, es aludido en el poema 38 (vv. 129-31: «No su semblante o su color se muda / porque mude color, mude semblante / el señor a quien sirve»): se trata del camaleón, que se alimenta de aire y cambia de colores constantemente, símbolo de los aduladores cortesanos, que remite directamente a otro de los emblemas de Alciato (53), «In adulatores»: «El camaleón siempre bosteza, siempre lleva atrás y adelante la brisa sutil de la que se alimenta, y cambia de aspecto y asume distintos colores [...] Del mismo modo hace ir y venir el rumor del pueblo al adulador y bostezando lo devora todo, y solo imita del príncipe las costumbres oscuras». Es la misma imagen que aduce Góngora en las Soledades (I, vv. 108 y ss.) en el discurso del peregrino sobre los males de la corte en lá que mora la ambición «hidrópica de viento".

En el sector de las poesías que podemos llamar sacras destacan dos poemas a Fray Pedro Padilla $(163,164)$ y la Canción a la Virgen de Guadalupe del Persiles (150). En los primeros volvemos a encontrar la imagen del mar del mundo ${ }^{50}$, muy desarrollada, mar que atraviesa Padilla como experto marinero en su camino hacia el cielo. En ese desarrollo se incluye la imagen específica de una nave

50 Ver para esta modulación exactamente religiosa RAHNER, "Il mare del mondo», en L'ecclesiologia dei Padri, 455-510. 
(nave de la Iglesia, mejor que el arca de Noé, la cual es su prefiguración), el mar del mundo, las áncoras (símbolo de la esperanza), la brújula... en un despliegue muy rico de motivos emblemáticos:

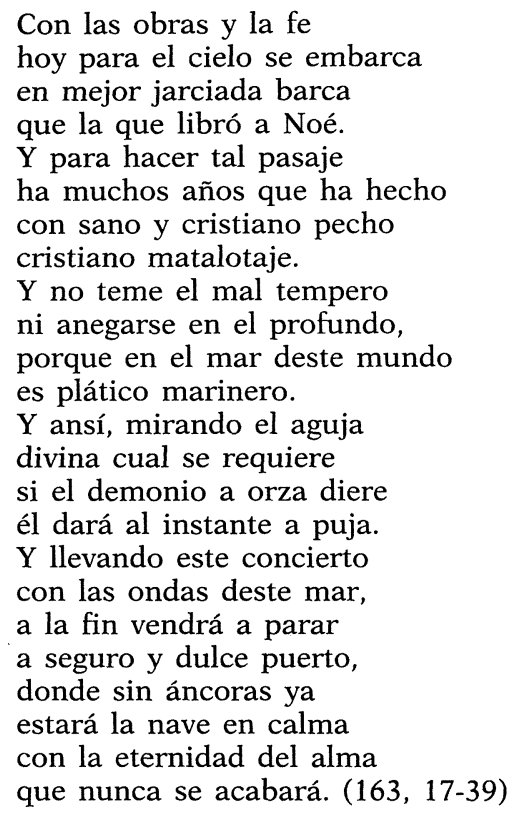

Además de éste, y otras referencias menos interesantes, hay otros tres motivos fundamentales asignados a Padilla.

El primero es el de la muda de la serpiente (163, 9-12: «Cual prudente sierpe ha sido, / pues con nuevo corazón / en la piedra de Simón / se deja el viejo vestido"), que establece una agudeza de proporción con la circunstancia que provoca el poema, la toma del hábito religioso, y que se conecta con el texto de San Pablo sobre el hombre nuevo ${ }^{51}$.

51 Son conocidos los lugares de San Pablo sobre el hombre viejo y el nuevo, vivificado por la gracia de Cristo: Efesios, 4, 22-24: "deponere vos secundum pristinam conversationem veterem hominem qui corrumpitur secundum desideria erroris. Renovamini autem spiritu mentis vestrae et induite novum hominem, qui secundum Deum creatus est in justitia et sanctitate veritatis" ('os revestís del hombre nuevo creado a imagen de Dios'), y en Colosenses, 3, 9 ss. 'despojaos del hombre viejo y sus acciones, y revestíos del hombre nuevo' ( $N$ Nolite mentiri invicem, expoliantes vos veterem hominem cum actibus suis, et induentes novum, eum qui renovatur in agnitionem, secundum imaginem eius qui creavit illum... Induite vos ergo sicut electi Dei, sancti, et dilecti, viscera misericordiae, benignitatem, humilitatem, modestiam, patientiam...»). 
La serpiente muda de piel arrastrándose entre dos piedras juntas, para sacarse la vieja. Villava en la empresa 40 del Libro I (fols. 93 y ss.) sobre el mortificado, con el lema "Pugnare necesse est», representa una culebra luchando en la grieta de una piedra para mudar «la piel antigua, denegrida y fea», pues según Plinio y Aristóteles «para dejarse el pellejo antiguo y cobrar otro nuevo y luciente, pelea entre duras piedras, por donde dice Pierio que es símbolo del que habiendo salido de algún trabajo se restituye a estado mejor» ${ }^{52}$.

El segundo es otro símbolo de renovación, el águila que renueva la pluma vieja:

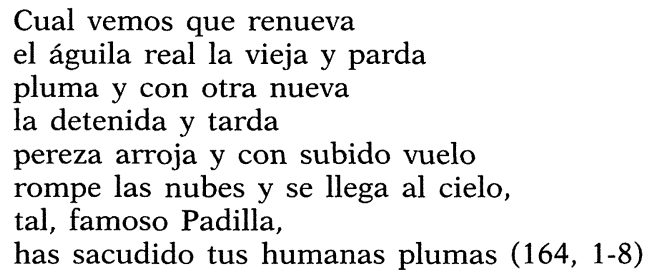

Es rasgo que aducen emblemas como el de Borja (12-13) «Vetustate relicta», Valeriano (fol. 141), Camerarius (emblema XVI del libro de las aves) y otros que recogen Henkel-Schöne (cols. 775-77).

El más cercano al sentido del texto cervantino es el de Borja, que especifica el modo de renovación de las plumas, quemadas por el sol al volar el águila hacia el astro; si se tiene en cuenta (ver más abajo) que el sol es símbolo de Cristo, se comprenderá la precisión de la referencia en este lugar concreto de Cervantes, iluminada por el comentario de Borja: «se escribe que el águila lo hace [renovarse] volando tan alto hacia el sol que con sus rayos la abrasa y quema las plumas, y dando consigo en el agua queda con nuevas plumas y nuevas fuerzas; lo mismo nos acontecerá si queremos llegarnos tanto a nuestro sol de justicia que nos abrase y nos renueve; que es lo que se da a entender por esta empresa del águila que vuela hacia el sol con la letra Vetustate relicta, que quiere decir "Dejada la vejez"».

El tercer motivo es el del sol que alza de la tierra los vapores de la humedad para devolverlos después en lluvia benéfica: de esa manera el sol divino toca a Padilla, el cual devuelve luego en forma de doctrina y santo ejemplo esa humedad que remedia la sequedad de la ignorancia que el locutor poético se atribuye $(164,13-$

\footnotetext{
52 Más ejemplos en HENKEL-SchöNE, cols. 634-35.
} 
24). Es el mismo emblema que trae Villava, libro I, empresa 14, con igual aplicación a los apóstoles predicadores de la doctrina cristiana de cuyas bocas "había salido el diluvio de aguas tan gloriosas»: «Viva figura de los apóstoles sagrados, que siendo unos olvidados pescadores los levantó el sol de justicia Cristo del mar de Galilea, y esparcidos como nubes con el viento del Espíritu Santo, que les sopló el día de Pentecostés, volaron por diversas provincias, regando la tierra con la palabra del Señor. No en vano, pues, a un apóstol se le da esta empresa».

Este poema 164 en realidad se estructura sobre los dos motivos del águila y del sol que toma la humedad, elaborados paralelamente y en dos partes cada uno: primero se presenta el motivo emblemático y luego se explica el sentido que tiene al aplicarse a Padilla. Puede decirse que toda la pieza consiste en la exposición de dos emblemas con su comentario.

La Canción a la Virgen de Guadalupe, merecedora de un análisis específico que ahora no puedo hacer, tiene una gran riqueza de material emblemático muy localizado en la figura de la Virgen y sus cualidades y atributos ${ }^{53}$.

Se suceden en el poema los símbolos de la casa fundada en las virtudes teologales, el alcázar, con pozos, fuentes, huertos cerrados con palmas, cedros, plátanos y rosas de Jericó, el templo de Salomón, espejo, estrella, aurora del verdadero sol, paloma madre del cordero manso...

Es una especie de letanía que incluye, como se ve, numerosos motivos, la mayor parte de los cuales hallará documentados el lector curioso en un libro de jeroglíficos dedicado a la Virgen por Fray Nicolás de la Iglesia, las Flores de Miraflores, Hieroglíficos Sagrados... Alargaría mucho estas páginas el comentario de todos ellos, que remiten en buena parte a la imaginería de la Esposa del Cantar de los cantares de Salomón. Daré, pues, solo algunos breves apuntes de los principales.

María es ciudad fortificada, alcázar y castillo celestial (ver por ejemplo los jeroglíficos 22, 23 de Flores de Miraflores); pozo de aguas vivas (jeroglífico 26, según la comparación del Cantar de los cantares de la Esposa con el pozo de aguas vivas); huerto cerrado (jeroglífico 27, donde comenta el Cantar de los cantares: «figúrase también en la clausura del huerto de nuevo repetida la espiritual virginidad y pureza enterísima del alma»); se compara con la palma, ciprés y cedro, plantas de intensa presencia en los catálogos

53 Para un análisis de otro tipo de imágenes, algunas relacionadas con las que arriba comento, ver P. MicozZI, "Imágenes metafóricas en la canción a la Virgen de Guadalupe». 
de emblemas, signos de la victoria, la resistencia, el triunfo, y de la eternidad e incorruptibilidad ${ }^{54}$; el espejo sin mancha representa la limpieza «espejo en quien se mira toda la corte celestial, espejo que en la sala de la Iglesia hace correspondencia con el espejo Cristo de quien dijo la Sabiduría "Candor est lucis aeterna speculum sine macula»» (Flores de Miraflores, jeroglífico 47)...

La Virgen es aurora del verdadero sol, Cristo. El sol, como símbolo de la divinidad, fuente de toda luz, es también muy conocido, y goza en la tradición cristiana de amplia representación. Ruperto Abad llama a Cristo «sol de justicia, nacido de María, que ilumina el mundo entero» (ML, 168, col. 361). Alain de Lille hace un comentario del mismo simbolismo, a partir del texto de Isaías, 62, 1, y comentario similar se encuentra en S. Fulgencio (ML, 65, col. 544), o San Agustín (sermón 68, 7 y otros muchos pasajes) ${ }^{55}$.

Sintetiza Fray Luis de Granada ${ }^{56}$ : «tales son las propriedades y

54 El cedro es árbol de rica simbología; los del Líbano eran especialmente famosos, y se citan innumerablemente en la Biblia. Para el simbolismo del cedro baste remitir al extenso comentario de C. a Lapide (IX, 633-34) donde se glosa la altura, imputrescencia, aroma y belleza de los cedros del Líbano: «cedrus inter arbores eminet, primo altitudine [...] Adde cedrus amat montes; pari modo altissima est Sapientia, qui ad coelos et deum pertingit; docet enim coelestem et divinam doctrinam [...] secundo, rectitudine, cedrus enim enodis [...] tertio, soliditate [...] quarto incorruptione; cedrus enim cariem, tinem et vetustatem non sentit [...] quinto, duratione; cedrus enim diutissime durat; unde aeterna indigitatur [...] sexto, fructu [...] septimo, odore; odorata enim est cedrus, ideoque incorrupta et aeterna. Hinc cedrus suo odore fugat et occidit serpentes». La palma es más preciada en su significación de virtud, que cualquier riqueza, como expresa el emblema de Gilles Corrozet (Hecatongraphie) "Vertu meilleure que richesse», donde se representa una balanza en que la palma vence a la corona y al trono. Añádase algún trozo del comentario de C. a Lapide (IX, 635, 2-637, 1): «enim longeva este, ideoque aeternitatis symbolum [...] palma excellit robore, coma, duratione, nisu in superna, aequalitate, fructu [...] robusta, comata, aeterna, sursum vergens ac contra omnia adversa in coelum enitens et eluctans... palma victoriae symbolum est, nec cedit oneri... sed contra pondus resurgit». Añádase para la palma, en HENKEL-SCHÖNE, emblemas de SAAVEDRA FAJARDO, col. 194; JUNIUS, col. 195; ANULUS, col. 197; Lebeus-Batillius, col. 198; Camerarius, col. 198; Sebastián De CovarRubias, col. 200; para el cedro, PIERo VAleriano, Hieroglyphica, BASIleAe, 1556, 373v.: "Ante alias enim arbores Cedrus aeternitatis hieroglyphicum est, qui materia eius neque putrescit neque cariem patitur. Hinc Arca foederis ex cedro fabrefacta est. Et cedro digna loqui dicuntur illi qui ea scribunt quae nulla temporis iniuria sit abolitura".

55 Véase, en fin, C. a Lapide, quien comenta con abundancia de detalles distintos sentidos y matices simbólicos del sol: símbolo de Dios (V, 117, 1; XVII, 328, 2; XIX, 352, 1, 2); imagen de la voluntad divina (XXI, 37, 1); símbolo de la divinidad y Dios de justicia (X, 29, 1); símbolo de Cristo (X, 390, 1; XVIII, 224, 2); el sol naciente simboliza a Cristo (XIV, 389, 1, 2); sol de justicia es Cristo en su primera venida, por varias analogías (XIV, 606, 2); sol refulgente es Cristo (XXI, 35, 2; 36, 1); sol naciente y sol poniente son símbolos de Cristo (XVII, 48, 2), etc.

56 Introducción al símbolo de la fe, ed. BALCELLS, 197. 
excelencias desta estrella, que con no ser las criaturas, como dicen, más que una pequeña sombra o huella del Criador [...] todavía entre las criaturas corporales, la que más representa la hermosura y omnipotencia del Criador en muchas cosas, es el sol».

Sobre el simbolismo mariano de la paloma ya han quedado algunas observaciones más arriba.

Cristo es llamado Cordero en numerosos lugares: "Cordero, pasándolo a Cristo, dice tres cosas: mansedumbre de condición, y pureza e inocencia de vida, y satisfacción de sacrificio y ofrenda» (Fray Luis de León, De los nombres de Cristo). Es símbolo muy frecuente y rico en las Sagradas Escrituras ${ }^{57}$ : en el libro de Isaías, 53, 6-8, el cordero es prefiguración de Cristo y su sacrificio en la cruz, lo que glosa San Atanasio, MG, 26, col. 1365: en la Eucaristía se inmola el cordero conducido como oveja al matadero y no dice palabra, como cordero delante del matarife. En la liturgia de la comunión: «Ecce agnus Dei, ecce qui tollit peccata mundi». Otro de los pasajes elaborados sobre este simbolismo es el del Apocalipsis, 14; id., 21, etc.

En su conjunto la Canción a la Virgen de Guadalupe constituye una serie continua de elementos emblemáticos que sólo desde el examen de esta tradición simbólica -enraizada en textos de las Sagradas Escrituras y en sus glosas patrísticas- cabe comprender.

\subsection{Emblemas en poemas épicos y cortesanos}

El último terreno en el que se advierte una explotación sistemática de los emblemas en la poesía de Cervantes es el de los poemas cortesanos y épicos. Me centraré solamente en el romance de la misa de parida de la reina doña Margarita, de La gitanilla (131), y en la Canción Segunda a la Armada contra Inglaterra (172).

El cortejo real salió a la misa de parida de la reina el 31 de mayo de 1605, a la iglesia de Nuestra Señora de San Llorente (Lorenzo) de Valladolid, tras el nacimiento del que sería Felipe IV. En el poema se califica a Felipe III de "sol de Austria» (v. 11), se ataca a la "envidia mordedora» (vv. 53-54), aplica al matrimonio real el emblema de la vid y el olmo (65-68), usa la metáfora de la paloma para la reina, que producirá por crías «águilas de dos coronas» (vv. 73 y ss.) y se refiere al templo por medio de una perífrasis alusiva al «Fénix santo" (v. 94) que apunta a San Lorenzo, martirizado en unas parrillas al fuego, por lo que se puede comparar con el ave fénix.

57 Ver para más detalles el artículo "Agneau de Dieu», en Vigoroux, Dictionnaire. Emblemas en HENKEL-ScHÖNE, cols. 540 y ss. y Flores de Miraflores, jeroglíficos $18,46,48$. 
Casi todos estos motivos han sido comentados. Añadiré aquí sólo el valor heráldico del águila bicéfala, y la imagen implícita de la Envidia.

Es Ferrer de Valdecebro quien más largamente ha escrito sobre el águila en su Libro Primero de Gobierno general, moral y politico hallado en las aves, donde la califica de «la reina de las aves y princesa coronada de los vientos, pájaro el más noble y generoso de cuantos viven en la esfera clara y transparente de los aires». De esa nobleza procede su valor heráldico.

En lo que se refiere al águila imperial alemana parece haber sido adoptada por Carlomagno como símbolo del imperio. Su origen más remoto pudieron ser las dos águilas que aparecieron el día del nacimiento de Alejandro Magno y que han quedado incorporadas en las armas imperiales (Covarrubias, Tesoro).

Un trabajo reciente de Galindo Blasco ${ }^{58}$ comenta la frecuencia del emblema del águila como símbolo imperial en las exequias valencianas de José I de Austria, dinastía que tomó este animal como signo de identidad, entre otros muchos reyes y emperadores de todas las épocas y latitudes que acudieron a él para expresar su nobleza.

El águila bicéfala coronada significa en sus dos cabezas el poder de uno y otro imperio, oriental y occidental (Covarrubias, Tesoro).

La Envidia se representa habitualmente como una vieja que muerde su propio corazón y se alimenta de víboras: traduce Daza Pinciano a Alciato: "Por declarar la invidia y sus enojos / pintaron una vieja que comía / víboras, y con mal contino de ojos. / Su propio corazón muerde a porfía» (p. 254). C. Ripa (I, 341-44) comenta varias representaciones: «Mujer delgada, vieja, fea y de lívido color. Ha de tener desnudo el pecho izquierdo, mordiéndolo una sierpe [...] la serpiente [...] simboliza el remordimiento que permanentemente desgarra el corazón del envidioso»; "va vestida del color de la herrumbre, destocada y con los cabellos entreverados de sierpes». Góngora en Soledad I evoca a la envidia cortesana como «la que su alimento / el áspid es gitano».

En la Canción a la Armada, de tono épico y lamentativo por el fracaso de la expedición, se suceden lugares emblemáticos en la evocación de la "calva ocasión» (21-23) que no ha sido propicia, en la figura del león como símbolo del rey (35 y ss.), en la roca firme a los embates del mar (120 y ss), etc.

Dos nuevos motivos importantes se suman en esta composición al ya largo repertorio cervantino: la columna (el rey es columna de

58 ESTHER GALINDO BLASCO, «El penúltimo homenaje a la casa de Austria en Barcelona. Los emblemas en las exequias del emperador José I». 
la fe, 54) es el primero: «sinifica apoyo, firmeza, sustento, estabilidad, inmutabilidad. Destas acepciones se sacan muchos símbolos y hieroglíficos» escribe Covarrubias en el Tesoro. Cornelio a Lapide ${ }^{59}$ comenta numerosas imágenes de columnas y sus sentidos simbólicos; Ripa (II, 327 y ss.) la trae como emblema de la sublimidad de la gloria, y Saavedra (empresa 31) la pone como emblema de la reputación de los príncipes. Villava en las Empresas espirituales y morales (Libro I, empresa 36) reproduce una columna firme y derecha como símbolo del constante y del que está rectamente referido a Dios.

El segundo es una alusión a la «planta / que al cielo con la carga se levanta» (117-18) como expresión de los bríos españoles, que con las adversidades se crecen. La comparación no se entenderá sin referirse a una de las características de la palma, la de resurgir contra el peso, según consignan con frecuencia los libros de emblemas: véase el de Taurellus «Sursum defexa recurret» (Emblemata physico ethica, en Henkel-Schöne, col. 196) o el más conocido de Alciato (emblema 36): «la palmera aguanta el peso y se levanta en arco y cuanto más se la presiona más levanta la carga» ${ }^{60}$.

\section{FINAL}

El catálogo revisado no incluye todos los motivos simbólicos de la poesía de Cervantes que se localizan en distintas colecciones de emblemas ${ }^{61}$ ni todas las ocurrencias de los comentados, pero sí los más significativos.

De ellos se pueden sacar algunas conclusiones: la primera es que la presencia de los emblemas en la poesía cervantina es enorme, y constituye, sin duda alguna, un modelo de expresión privilegiado.

La mayoría de referencias se instalan en un elevado grado de topicidad, aunque apunta en algunas el juego de ingenio conceptista. Las implicaciones visuales del género no redundan en Cervantes en la calidad sensorial de sus poemas, muy escasa: para Cervantes la percepción del simbolismo emblemático es una operación eminentemente intelectual.

\footnotetext{
59 Ver el índice de PÉronne para los lugares de C. a LAPIDE en sus Comentarii. Ver también BORJA, 360.

60 Ver J. M. Díaz Bustamante, "Notas a la tradición simbólica y emblemática de la palmera».

61 Algunos ejemplos más: corneja, búho, 95, 21, 26; veleta, 109, 3; Atlante, 156, 115-16; Hércules, $38,30 \ldots$ De todos modos los más significativos, sistemáticos y estructurados son los que quedan glosados arriba.
} 
Sí es rasgo característico la sistematización cervantina de los emblemas en campos bien definidos: el amor, la gloria literaria, y los temas sacros, cortesanos y épicos. En cada uno Cervantes selecciona los motivos más apropiados a la expresión de los temas dominantes: la abundancia y precisa selección de estos materiales revelan el uso consciente que de ellos hace el discurso poético cervantino como uno de sus constituyentes expresivos fundamentales.

IGNACIO ARELLANO

Universidad de Navarra

\section{BIBLIOGRAFÍA CITADA Y ABREVIATURAS DE REFERENCIAS BIBLIOGRÁFICAS}

Cito aquí con sus datos completos los libros y artículos que manejo, con las fechas de publicación de los ejemplares que uso. Los repertorios emblemáticos que veo a través de Henkel-Schöne, me limito a citarlos en mi comentario, pero no se recogen en la Bibliografía.

Actas del I Simposio Internacional de Emblemática. Teruel, Instituto de Estudios Turolenses, 1994.

Alciato, A., Emblemas, al cuidado de MARIO SoRIA. Madrid, Editora Nacional, 1975. - Emblemas, ed. S. Sebastián. Madrid, Akal, 1993.

Álvarez, M. C., «Emblematic aspects of Cervantes' Narrative Prose», A Celebration of Cervantes on the Fourth Centenary of La Galatea, Número especial de Cervantes, 1988, 149-58.

BAuer, H., «Emblematik im Drama Calderóns», Der Index Pictorius Calderóns. Hamburg, De Gruyter, 1969, 190-215.

Bernat Vistarini, A., "Algunos motivos emblemáticos en la poesía de Cervantes», Actas del II Congreso de la Asociación de Cervantistas, ed. G. Grilli. Napoli, 1995, 83-95.

BLANCO, E., «La imagen del castillo: un tópico religioso y político en la emblemática del siglo XVII", Literatura emblemática, 329-42.

BORJA, JUAN DE, Empresas morales, ed. facsímil de C. Bravo Villasante. Madrid, FUE, 1981, que reproduce la de 1680 preparada, con añadidos, por Francisco de Borja, nieto del autor, el cual la había sacado en primera edición en 1581 .

Bouzy, Ch., "Emblemas, empresas y hieroglíficos en el Tesoro de la Lengua de Sebastián de Covarrubias», en Literatura emblemática, 13-42.

CALDERón, P., Triunfar muriendo, ed. facsímil del autógrafo de I. Arellano, B. Oteiza y M. C. Pinillos. Kassel, Reichenberger, 1997.

CAMERARIUS, J., Symbolorum et emblematum ex aquatilibus et reptilibus, 1604. Ver Henkel-Schöne.

CAMPA, F., Emblemata Hispanica. Durham, Duke U. P., 1990.

Cervantes, M. DE, Poesías completas, ed. V. Gaos. Madrid, Castalia, II, 1981. (Vol. I, 1973).

CovarRubias, S. DE, Emblemas morales, ed. facsímil de C. Bravo Villasante. Madrid, FUE, 1978. 
CovarRubias, S. DE, Tesoro de la lengua castellana o española. Madrid, Turner 1979.

Cull, J., «Heroic Striving and Don Quijote's Emblematic Prudence», Bulletin of Hispanic Studies, 67, 1990, 265-77.

- «Emblem motifs in Persiles y Sigismunda», Romance Notes, XXXII, 1992, 199-208.

- "Death as Great Equalizer in Emblems and in Don Quijote», Hispania, 75 1992, 8-17.

- "Emblematics in Calderón's El médico de su honra», Bulletin of the comediantes, 44, 1, 1992, 113-31.

DEmETZ, P., "The Elm and the Vine: Notes Toward the History of a Marriage Topos», PMLA, 73, 1958, 531-32.

Díaz Bustamante, J. M., "Notas a la tradición simbólica y emblemática de la palmera. Onerata resurgit», Helmántica, 94, 1980.

EGIDO, A., "Emblemática y literatura en el Siglo de Oro», Ephialte, 2, 1990, 144-158.

- "Variaciones sobre la vid y el olmo en la poesía de Quevedo», Homenaje a Quevedo, ed. V. García de la Concha. Salamanca, Universidad, 1982, 213-32.

FERRER DE VALDECEBRo, A., Gobierno general, moral y politico hallado en las aves. Madrid, Melchor Alegre, 1670.

- Gobierno general, moral y político hallado en las fieras, Barcelona. Cormellas 1696.

GALINDO BLASCO, E., «El penúltimo homenaje a la casa de Austria en Barcelona. Los emblemas en las exequias del emperador José I", Actas del I Simposio, 539-66.

GÁllego, J., Visión y símbolos en la pintura española del Siglo de Oro. Madrid, Cátedra, 1991.

García MaHiQues, R., Empresas sacras de Núñez de Cepeda. Madrid, Tuero, 1988.

Gracián, B., El Criticón, ed. M. Romera Navarro. Filadelfia, University of Pennsylvania Press, 1938-40.

GRANADA, FRAY LUIS DE, Introducción al símbolo de la fe, ed. J. M. Balcells. Madrid, Cátedra, 1989

Halkhoree, P., "Lope de Vega's El villano en su rincón, as emblematic Play», Romance Notes, 14, 1972-73, 141-145.

Hebreo, León, Diálogos de amor, ed. J. M. Reyes. Barcelona, PPU, 1986.

HENKEL, A. y SchönE, A., Emblemata. Stuttgart, 1976.

HillaCH, A., "Sakramentale Emblematik bei Calderón», Emblem und Emblematikrezeption, ed. S. Penkert. Darmstadt, Wissenschaftliche, 1978, 194-206.

HoRAPOlo, Hieroglyphica, ed. J. M. González de Zárate. Madrid, Akal, 1991.

HoRozco, JUAN DE, Emblemas morales. Segovia, Juan de la Cuesta, 1589.

IGLESIA, NiCOLÁS DE LA, Flores de Miraflores, hieroglificos sagrados, verdades figuradas, sombras verdaderas del misterio de la Inmaculada Concepción de la Virgen. Burgos, Diego de Nieva, 1659.

INFANTES, V., "La presencia de una ausencia. La emblemática sin emblemas», Literatura emblemática, 93-109.

- "Calderón y la literatura jeroglífica», Calderón. Actas del Congreso Internacional, ed. L. García Lorenzo. Madrid, CSIC, 1983, III, 1593-1602.

LAPIDE, C. a, Comentarii... R. P. Cornelii a Lapide. Paris, Ludovicum Vives, 1878.

LEDDA, G., Contributo allo studio della letteratura emblematica in Spagna, 1549-1613. Pisa, Giardini, 1970.

- "Los jeroglíficos en los sermones barrocos», Literatura emblemática, 111-128.

LEÓn, Fray LuIs DE, De los nombres de Cristo, ed. C. Cuevas. Madrid, Cátedra, 1984

Literatura emblemática hispánica, ed. S. LóPEz PozA. La Coruña, Universidad, 1996.

MalaXecheVerría, I., Bestiario medieval. Madrid, Siruela, 1986.

MANERo, M. P., Imágenes petrarquistas en la lírica española del Renacimiento. Repertorio. Barcelona, PPU, 1990. 
- «Aproximaciones al estudio del petrarquismo en la poesía de Cervantes: la configuración imaginística del amante», Actas del II Coloquio Internacional de la Asociación de Cervantistas. Barcelona, Anthropos, 1991, 755-79.

MARAVALL, J. A., "La literatura de emblemas en el contexto de la sociedad barroca", en Teatro y literatura en la sociedad barroca. Barcelona, Crítica, 1990, 92-118.

MARTINS, H., "La Estrella de Sevilla como emblema», Barroco, 1, 1969, 75-79.

MENDO, ANDRÉs, Príncipe perfecto, León de Francia, Horacio Boissat y George Remeus, 1662.

MG, Patrologia graeca, de Migne, indicando tomo y columna.

MicozZI, P., «Imágenes metafóricas en la canción a la Virgen de Guadalupe», Actas del II Congreso de la Asociación de Cervantistas, ed. G. Grilli. Napoli, 1995, 711-23.

ML, Patrologia latina, de Migne, indicando tomo y columna.

MoIR, D. W., "Lope de Vega's Fuenteovejuna and the Emblemas morales of Sebastián de Covarrubias Horozco", Homenaje a W. Fichter. Madrid, Castalia, 1971, 537-46.

NÚNEEZ DE CEPEDA, ver García Mahiques.

PÉREZ DE Moya, J., Filosofía secreta, ed. E. Gómez de Baquero. Madrid, NBAE, 1928.

PINEDA, P., Diálogos de agricultura cristiana, BAE, vol. 170.

PRAZ, M., Imágenes del barroco. Madrid, Siruela, 1989.

Quevedo, F. DE, Sueños, ed. I. Arellano. Madrid, Cátedra, 1991.

RaHner, H., L'ecclesiologia dei Padri. Roma, Edizioni Paoline, 1971

RODRíGUEZ DE LA FLOR, F., Emblemas. Lecturas de la imagen simbólica. Madrid, Alianza, 1995.

RIPA, C., Iconología. Madrid, Akal, 1987, 2 vols.

SAAVEDRA FAJARDO, D., Empresas políticas, ed. facsímil de Murcia, Universidad, 1985.

SEBASTIÁn, S., Contrarreforma y Barroco. Madrid, Alianza, 1981.

SELIG, K. L., "Persiles y Sigismunda: Notes on Pictures, Portratits and Portraiture», Hispanic Review, 41, 1973, 305-312.

- "The Battle of the Sheep: Don Quijote I, 18», Revista Hispánica Moderna, 38 1974-75, 64-72.

- «Don Quijote I/8-9 y la granada», en De los romances-villancico a la poesía de Claudio Rodríguez, ed. J. M. López Abiada y A. López Bernasocchi. [Madrid] José Esteban, 1984, 401-7.

- «Don Quijote II, 16-17: Don Quijote and the Lion», Homenaje a A. M. Barrenechea, ed. I. Lerner y L. Schwartz. Madrid, Castalia, 1984, 327-32.

SMITH, D. L., "Tirso's Use of Emblems as a Technique of Representation in La mujer que manda en casa», Bulletin of the Comediantes, 37, 1, 1985, 71-81.

Soons, A., "Calderón dramatizes an Emblem: No hay cosa como callar», Arcadia, 6 , $1971,72-74$

SOTO, HERNANDO DE, Emblemas moralizadas, ed. facsímil de C. Bravo Villasante. Madrid, FUE, 1983.

SuÁREZ DE FIgUeroA, C., El pasajero, ed. I. López Bascuñana. Barcelona, PPU, 1988.

TURner, J. H., The Myth of Icarus in Spanish Renaissance Poetry. London, Tamesis, 1976.

UlmaNN, P., "An Emblematic Interpretation of Sansón Carrasco's Disguises», en Estudios literarios de hispanistas norteamericanos dedicados a $\mathrm{H}$. Halztfeld con motivo de su 80 aniversario, ed. J. M. Solá Solé, A. Crisafulli y B. Damiani. Barcelona, Hispam, 1974, 223-38.

VALBUENA BRIONES, Á., "La palabra sol en los textos calderonianos", en Calderón y la comedia nueva. Madrid, Espasa-Calpe, 1977, 106-118.

Valeriano, Piero, Hieroglyphica. Basileae, 1556.

Vigoroux, F. (dir.), Dictionnaire de la Bible. Paris, Letouzey, 1895

VillaVA, F. DE, Empresas espirituales y morales. Baeza, 1613.

Vitoria, BALTASAR DE, Teatro de los dioses de la gentilidad. Madrid, Imprenta Real, 1676. 